\title{
RAZÓN, UTOPÍA Y DISUTOPÍA
}

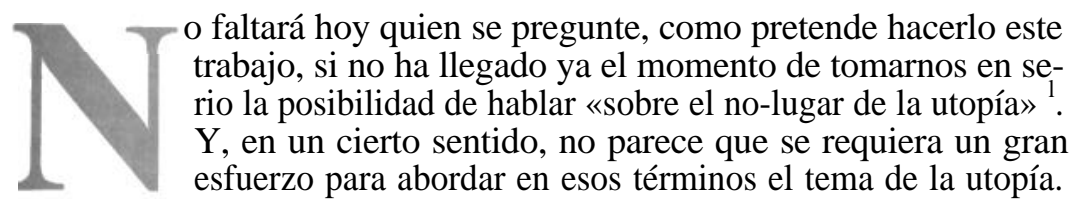

Pues aun cuando Oscar Wilde escribió un día que «un mapa del mundo que no incluya el país de la utopía no merece siquiera la pena de un vistazo», a nadie se le oculta que la belleza de su frase se ve realzada por el hecho de encerrar una palmaria contradicción. Por el contrario, la idea del no-lugar de la utopía no encierra nada de contradictorio y hasta pudiera dar la sensación, errónea o no, de expresar una tautología. Etimológicamente hablando al menos, si no en algún sentido más profundo, lo que caracteriza a la «utopía» es, en efecto, su «falta de lugar». ${ }^{2}$

A semejante inspiración debió de responder, en cualquier caso, la acuñación del término por Tomás Moro en su Utopía de 1516. Sin perjuicio de que Moro tuviese en cuenta en su obra -pues incluye la cita en el relato del viajero Hythloday- el memorial de Américo Vespucio sobre sus viajes al Nuevo Continente e islas adyacentes, lo cierto es que compuso dicho término -tan sutil como melancólicamente- a base de los vocablos griegos ou y tópos, a traducir por «en ningún sitio», Nowhere en la traducción inglesa del propio siglo XVI o «no hay tal lugar», como, en el siglo XVII, traduciría Quevedo al español. Y, como es asimismo bien sabido, fue la desconfianza hacia lo que no sólo no se halla realizado en parte alguna, sino que es harto dudoso que en parte alguna pueda hallar realización, lo que en definitiva impulsó a Engels a proponer la superación del utopismo en su opúsculo Del socialismo utópico al socialismo científico de 1882.

El caso es, sin embargo, que la cuestión resulta un tanto más complicada que como la acabamos de pintar. Pues, según Arnhelm Neusüss, la novela política a lo Moro o la crítica del utopismo a lo Engels no son las únicas fuentes del concepto de utopía, que asimismo se alimenta de -y sirve para designar a- «ciertas intenciones relacionadas con la realización de la convivencia social». ${ }^{3} \mathrm{Y}$ en lo que se ha dado en llamar «el concepto intencional de la utopía» parece, en cambio, inexcusable la referencia a un tópos que -además de deseable- se presume asequible o, cuando menos, se está le-

1 El trabajo que sigue constituye un fragmento del capítulo VIII de mi libro Desde la perplejidad, Madrid, Taurus, en prensa.

2 Véase sobre este punto mi trabajo «Sobre la falta de lugar de la utopía», en J. GonzálezC. Pereyra-G. Vargas Lozano (Eds.), Praxis y filosofia. Ensayos en homenaje a Adolfo Sánchez Vázquez. México-Buenos. Aires, Grijalbo, en prensa.

3 Cfr. A. Neusüss (ed.). Utopie. Begriff und Phänomen des Utopischen, Neuwied, 1968 (hay trad. Cast. de M. Nolla, Barcelona, 1971), Introducción, I, 3, donde el autor remite a Max Horkheimer, Anfänge der bürgerlichen Geschichtsphilosophie, Stuttgart, 1930 (hay trad. cast. de M. R. Zurro, Madrid, 1982), pp. 77-94. 
jos de considerar por principio inasequible, por más larga y dificultosa que haya de ser la ruta que nos conduzca hasta allí. En cuanto a la alusión a la «intención», se colige de ella que -para recorrer una tal ruta- no basta con la ciencia, sino que se requiere -además, claro, de una buena dosis de paciencia- la efectiva voluntad de recorrerla. Y de ahí que en el París del 68 se popularizase -con avieso designio antiengelsiano- la sustitución de la fórmula «del socialismo utópico al socialismo científico» por la fórmula inversa «del socialismo científico al socialismo utópico», acompañada en ocasiones de otros slogans bastante más voluntariosos que pacientes -como el de «seamos realistas, pidamos lo imposible»- de acomodo ciertamente difícil dentro de la intención utópica. Un pensador como Ernst Bloch, sin disputa el más grande cultivador del pensamiento utópico en nuestro siglo, habría aceptado sin reservas -aun si con precisiones, ya que lo suyo no era exactamente el desenfado del Mayo francés- la inversión de la fórmula de Engels, pero rechazó siempre, con la energía de quien no estaba para bromas al respecto, que la utopía por él reivindicada tuviese algo que ver con la propuesta de fantasías irrealizables. ${ }^{4}$ Aunque hoy por hoy no haya tal lugar, cabría decir, nada hay que presuponga en la utopía que nunca lo haya habido -el comunismo primitivo no era para Marx, comoquiera que sus críticos den en interpretar dicha hipótesis, el Jardín del Edén- ni que no lo haya de haber nunca, pues el advenimiento de la sociedad comunista en el futuro no equivalía tampoco para Marx -comoquiera, de nuevo, que sus críticos den en interpretar ese proyecto, que es por tanto en sí mismo algo más que una hipótesis teórica- a la eclosión del Quiliasmo.

Por el contrario, y desde el punto de vista de la intención que la anima, cabría afirmar que la utopía es contraria a los hechos únicamente en la medida en que aquélla entraña una preferencia moral por otros hechos, de suerte que su contrafacticidad sería perfectamente compatible con su «sed de facticidad», esto es, con la pretensión de que tengan lugar aquellos hechos en los que la utopía busca encontrar su cumplimiento. Y no hay que olvidar que una tal peculiaridad de la utopía ni tan siquiera se halla ausente de la Utopía de Moro, quien se permitió allí jugar con la posibilidad de hacer derivar la «u» inicial de esa palabra del prefijo griego $e u$, con lo que -más que «ningún lugar»- la utopía, o sea la eutopía, vendría a querer decir «un buen lugar» o lugar digno de convertirse en realidad. Pues bien, es semejante «visión eutópica» de la utopía la que parece haber entrado en crisis en los últimos tiempos, y habría que comenzar por preguntarse por qué ha ocurrido así.

Como ha señalado Karl-Otto Apel, quienquiera que en las modernas sociedades industriales avanzadas reflexione sobre la ética se enfrenta a una situación que bien cabría tildar de paradójica. De acuerdo con su descripción, la mencionada situación paradójica estriba en lo siguiente: «Por una parte, la necesidad de una ética universal, es decir, de una

4 En cuanto a lo primero, véase ya su caracterización del «pensamiento socialista» en Geist der Utopie, $2^{\mathrm{a}}$ ed., 1923 (Gesamtausgabe, 16 vols. Francfort del Main, vol. III, 1964), pp. 293-307; y, para lo segundo, su -en cualquier caso, positiva- toma de posición ante «el movimiento estudiantil» en «Die neue Linke und die Tradition», Abschied von der Utopie?, ed. Hanna Gekle, Francfort, 1980, pp. 155-82. 
ética que vincule a la sociedad humana en su conjunto, nunca ha sido tan acuciante como en nuestra época, caracterizada por una civilización uniforme a escala planetaria producto de las consecuencias tecnológicas de la ciencia. Por otra parte, la tarea filosófica de fundamentación racional de una ética general nunca ha parecido tropezar con tantas dificultades como en esta era científica, debido a que en ella la noción de validez intersubjetiva se halla asimismo prejuzgada por la ciencia, a saber, por la noción ciencista de una objetividad normativamente neutral o libre de valores». ${ }^{5}$ Examinemos uno tras otro ambos aspectos de la paradoja. Quien todavía hoy se interese por ese tipo de cuestiones difícilmente negará que la época en que vivimos -presidida como en efecto lo está por una civilización científico-técnica planetariamente uniforme- hace imperiosa la necesidad de una ética de alcance asimismo universal, esto es, capaz de dirigirse a la humanidad considerada como un todo más bien que tales a cuales sectores de la misma ideológicamente escindidos entre sí, cuyas mutuas relaciones habría que abandonar en otro caso a la insegura suerte de una lucha darwiniana por la supervivencia. Cuanto se acaba de decir parece al menos cierto de lo que se ha dado en llamar «la macroética de la sociedad humana en el marco finito del planeta tierra», esto es, aquella pieza de ética que tendría a su cargo la consideración de las acciones humanas no en el microdominio o el nivel de la familia o las relaciones de proximidad, así como tampoco en el mesodominio representado por el nivel de las políticas nacionales, sino en el macrodominio o el nivel de lo que sin más llamaríamos el género humano, esto es, aquel dominio en que -a la vista de consecuencias tecnológicas de la ciencia tales como la amenaza de una conflagración nuclear- podría hoy decirse que se juega el destino de la humanidad. Mas, junto a ello, también es cierto que la ciencia y la técnica -y la filosofía que constituye en nuestros días su condensación ideológica y a la que, para abreviar, llamaremos positivismo- no sólo no coadyuvan a la construcción de tal ética universal sino que, en un cierto sentido, más bien cabría decir que tienden a excluir su posibilidad. El problema no es tanto que la noción de validez intersubjetiva -a que en definitiva se reduce, o en la que consiste, la objetividad- se halle o no expurgada en el ámbito de la ciencia de ingredientes valorativos, pues semejante expurgo nunca sería completo dentro de las ciencias humanas y sociales. Y ni siquiera lo es que desde el mundo de la ciencia -o, si se prefiere decir así, desde el mundo de los hechos, entiéndase lo que se desee entender por estos últimos- no quepa hacer gran cosa para asegurar la objetividad o validez intersubjetiva de nuestras normas, reglas o principios morales, pues es sabido que tales normas, reglas o principios no se dejan derivar, ni deductiva ni inductivamente, a partir de premisas fácticas. El problema es más bien que -dado que el ejercicio de la racionalidad vendría a constreñirse, en la interpretación positivista de la misma, al uso deductivo de nuestras capacidades racionales- las posibilidades de

5 K.-0. Apel, «Das Apriori der Kommunikationsgemeinschaft und die Grundlagen der Ethik (Zum Problem einer rationalen Begründung der Ethik im Zeitalter der Wissenschaft)», en Transformation der Philosophie, 2 vols., Francfort del Main, 1973 (hay trad. cast. de A. Cortina-J. Chamorro-J. Conill, en preparación), vol. II, pp. 358-435, pág. 359. 
la razón en lo tocante a la justificación de las acciones humanas quedarían severamente limitadas, puesto que en ningún caso habrían de rebasar los límites del uso científico de la razón. Las ciencias empíricas de la conducta podrían, sin duda, describir cómo operan nuestros sistemas de valores o explicarnos, sea en términos causales o estadísticos, la emergencia de los mismos, para todo lo cual no se precisa echar mano de juicios de valor. E incluso dados éstos -es decir, presupuestos tales o cuales valores a los que diéramos en considerar como fines de nuestros actos-, también estaría abierta la posibilidad de una tecnología de la conducta que contribuyese a garantizar la racionalidad del proceso de elección de los medios conducentes a la consecución de dichos fines. Mas de la racionalidad de los fines mismos ya no habría nada que decir, como no sea negar que exista una racionalidad de los fines, lo que es tanto como negar que exista razón práctica. En abierto contraste con la alegada objetividad de los juicios científicos, nuestros juicios morales serían no sólo irremisiblemente subjetivos sino, además, irracionales, pues su última fudamentación habría que confiarla -como lo propone el positivismo- a la irracionalidad de nuestras reacciones emocionales o nuestras decisiones arbitrarias. Para resumir, pues, su planteamiento de la «situación paradójica» que estamos comentando, cabría decir con Apel que «una ética universal -esto es, intersubjetivamente válida- de la responsabilidad colectiva parece hoy tan necesaria como imposible» ${ }^{6}$. Lo que equivale a decir que, de acuerdo con una bien conocida caracterización de la tragedia como punto de confluencia de la necesidad y de la imposibilidad, la mentada situación paradójica es lisa y llanamente una situación trágica.

En esta situación se hallan inmersos no sólo el positivismo, clásico o de nuestro siglo, sino asimismo los epígonos de este último -como sería el caso de la filosofía analítica- y hasta sus precursores, si damos en reputar de tal al Wittgenstein del Tractatus Logico-Philosophicus que emplazaba en él a la ética más allá de lo que se puede decir. Apel recuerda a este respecto la célebre carta de Wittgenstein a Ludwig von Ficker de 1919, en la que Wittgenstein no vacilaba en considerar al Tractatus como un libro de ética, añadiendo que el libro se componía de dos partes -la escrita y la no escritay que esta segunda era realmente la importante, pues su silencio acerca de la ética habría constituído la mejor expresión de lo que muchos intentaron articular y, a lo sumo, sólo lograron balbucir. Entre esos balbuceos, Apel incluye los de tradiciones de pensamiento tan aparentemente alejadas de la que venimos considerando como el existencialismo, de Kierkegaard a Jaspers, de la misma que compara el decisionismo analítico con la ética sartriana de la situación, llegando incluso a hablar de «una complementariedad entre objetivismo ciencista y subjetivismo ético»-o, como alguna vez también se ha dicho, entre «(neo)-positivismo» y «(neo)-romanticismo»- en la que cabría ver una característica fundamental del pensamiento contemporáneo. La acusada persistencia de actitudes neopositivistas en la filosofía de la ciencia y la presumible resurrección del existencialismo -o de actitudes

6 Para una fiel exposición de los puntos de vista que nos ocupan, véase Adela Cortina, «Pragmática trascendental y responsabilidad solidaria en Apel», Estudios filosóficos, 87, 1982, pp. 322-36. 
existencialistas, y en general neorrománticas, bajo otros ropajes filosóficosen la filosofía moral de nuestra última hora contribuirían a confirmar, en opinión de Apel, aquella complementariedad. Pero por sugestiva que resulte la tesis apeliana de la complementariedad, quedarse en ella equivaldría a algo así como a quedarse en la comprobación de que las siluetas actuales de los continentes geográficos se complementan o se corresponden entre sí, mas sin llegar a preguntar -a la manera de la teoría de la deriva continentalpor un posible origen común que dé razón de tal correspondencia o complementariedad, lo que en nuestro caso nos lleva a remontarnos a un continente originario, a saber, el continente de la Ilustración.

Tanto para bien como para mal, la Ilustración continúa suministrando el sustrato ideológico de nuestras sociedades industriales avanzadas, por lo menos en su modelo occidental; y digo que tanto para bien como para mal porque lo menos que se puede decir de su legado es que es ambiguo. Y, como Adorno y Horkheimer supieron apreciar, en pocos casos se revela mejor dicha ambigüedad que en aquella moneda de cuño ilustrado -a que acabamos de aludir- cuya cara romántica exalta nuestra capacidad moral de decisión y cuya cruz positivista la despoja de toda racionalidad, tras de haber reducido ésta a racionalidad científica. En la Ilustración, en efecto, tropezamos con un fenómeno lo suficientemente complejo como para poder considerar herencia suya tanto al positivismo como al romanticismo, así como a los respectivos herederos de uno y otro; y la presente situación paradójica, o trágica, de la ética no es sino el resultado de la explosiva coexistencia de tan dispares elementos en el seno del pensamiento contemporáneo.

Pero, por lo demás, querría llamar la atención sobre el hecho de que la tensión entre esos elementos -tensión cuyos efectos acaso puedan hoy ser deplorados- hubo de ser vivida originariamente, es decir, por la propia Ilustración, como una tensión no infecunda de la que se pensaba que la ética tendría que extraer provecho. Para la gran mayoría de los ilustrados, por ejemplo, la fe en la razón -alimentada por el éxito indudable de la moderna ciencia natural- llevaba a creer no sólo en la posibilidad de un conocimiento de la sociedad tan científico como el de la naturaleza sino, lo que es más, a creer asimismo en la posibilidad de reformar a dicha sociedad de acuerdo con dicho conocimiento. Como ha escrito Paul Lorenzen, aquellos a quienes llamamos en la actualidad «positivistas» se diferencian de los ilustrados precisamente por la pérdida de esa ingenua fe. De ahí que todavía luchen, como lo hacen, contra el oscurantismo en el terreno del conocimiento, pero hayan dejado de luchar por los cambios políticos. Y cuando alguien pretende elaborar una propuesta más o menos racional de lucha en tal sentido, tampoco es de extrañar que desde el positivismo se le aplique -como Ernst Topitsch lo ha hecho con intención abiertamente descalificadora- el calificativo de «romántico». Ahora bien, la tensión que hoy vivimos como resultado final de la disgregación de positivismo, u objetivismo ciencista, y romanticismo, o subjetivismo ético, es la misma tensión que movió a Kant a distinguir entre razón teórica y razón práctica. Pues Kant fue ciertamente un ilustrado eminente, mas avisado y no ingenuo, y no creía por tanto que la ciencia pudiera ahorrarnos la ética.

Pero si interpretamos al positivismo como la razón ilustrada menos sus ideales emancipatorios y al romanticismo -o, por lo menos, a un cierto 
romanticismo- como la perpetuación de esos ideales aun a costa de poner en cuestión a la razón ilustrada, habrá que conceder que Kant representa un punto de equilibrio anterior a la ruptura en dos mitades del legado de la Ilustración. Ahora bien, Kant no era exactamente un prepositivista ni un prerromántico, así como tampoco una simple suma de ambas actitudes contrapuestas, sino un filósofo moral para quien la distinción entre razón teórica y razón práctica -o entre un uso teórico y un uso práctico de la razónhundía sus raíces en una distinción, o una «tensión», más básica: la tensión entre el ser y el debe ser, tensión ésta que Kant -en abierto contraste con la actitud mayoritaria de los ilustrados- trató a ultranza de preservar, sin permitirse en ningún caso apaciguarla acortando el hiato que separa al ser del deber ser, esto es, a nuestro conocimiento más o menos científico de lo que la realidad es de los criterios de moralidad desde los cuales juzgar sobre lo que ésta deba ser. En la filosofía de nuestros días, y tal vez como muestra de la supervivencia de otros residuos ilustrados, la idea de acortar aquel hiato acostumbra a levantar de cuando en cuando polvoredas polémicas. Mas sólo para darnos la oportunidad de constatar, tras de sedimentarse éstas, que el dilema del ser y el deber ser (das Sein-Sollen Dilemma) resiste uno tras otro esos asaltos, tercamente enhiesto en su irresolución ${ }^{7}$. Probablemente hay más de una razón para celebrar que suceda así, comenzando por la de la supervivencia misma de la ética. Pero, de entre esas razones, nos interesa ahora retener la de que -gracias a semejante imposibilidad de transitar del ser al deber ser, que presupone la irreductibilidad del segundo al primero de ambos polos- cobra sentido la pregunta acerca de si, y cómo, sería posible el tránsito inverso del deber ser al ser, esto es, la «realización» de nuestros ideales morales: una realización a la que la intención utópica no podría renunciar sin traicionarse y negarse a sí misma. La condición indispensable para poder hacernos cargo de esta última parece estribar, pues, en la preservación de la bipolaridad del ser y el deber ser, y quienquiera que prescindiese de dicha distinción se vedaría todo posible acceso a la utopía.

Como Bloch ha hecho ver con más autoridad que nadie podría hacerlo, Hegel acaso constituya el ejemplo por la excelencia de lo que se acaba de apuntar. El interés de la filosofía por «lo que deba ser» condena a ésta fatalmente, según Hegel, a olvidarse del mundo y a perderse en el reino de las buenas intenciones. Mas la misión de la filosofía no habría de consistir en empedrar el infierno con sus intenciones piadosas, sino en levantar acta sin piedad de la actuación de la razón allí donde esta se produzca, aunque sea en el infierno. Y la razón actúa ni más ni menos que en la realidad, hasta el punto de llegar a identificarse con «lo que es». De suerte que el antedicho cometido notarial de la filosofía se reduce a la postre al de dar fe de que, en efecto, lo que es real es racional. Pero eso deja al hombre éticamente inerme ante la supremacía del acontecer histórico, pues del acierto o desacierto de sus decisiones mora-

7 Entre esos asaltos fallidos se cuentan, desde luego, los imprudentemente acometidos aquí y allá en mi libro La razón sin esperanza, Madrid, Taurus, 1977 (2ª ed., Madrid, Taurus, en prensa). 
les sólo cabría juzgar tras de emitir aquél su veredicto sobre el éxito o el fracaso de las mismas. Y de ahí que la historia haya de culminar indefectiblemente en un «¡Ay de los vencidos!», puesto que la razón estará siempre de parte de los vencedores. Cierto es que, para hacer justicia a Hegel, habría que recordar que al aserto de que «lo que es real es racional» anteponía el aserto de que «lo que es racional es real», aserto éste que -por más que no impida, ciertamente, nuestra reconciliación con cualquier pasado- al menos entreabre una puerta al futuro, esto es, a la futura posibilidad de que la identidad del mundo y la razón no sea mañana tan atroz como hoy. Mas, como advierte el propio Bloch, no sería Hegel ya, sino el marxismo, el llamado a asomarse a esa puerta entreabierta.

Ese marxismo no era para Bloch un marxismo cualquiera, sino un marxismo que habría de ser capaz de dar cabida en su interior a una "crítica de la razón práctica» ${ }^{8} \mathrm{y}$, por ende, a una ética que Bloch -aun si con alguna reserva- no dejó de identificar con la ética kantiana, como lo muestra su elocuente valoración del imperativo categórico de Kant: «Tomemos la proposición... de que el hombre no debe nunca ser un mero medio, sino siempre un fin. Esto nos lo enseña Kant, y por desgracia es evidente que lo que se nos dice con ello no pasa de ser una exigencia... Ahora bien, ¿y si la proposición de Kant, tan rígida al parecer, se anticipara justamente a su época? ¿Y si en su dirección contuviera una audacia y una dicha que sólo esperaran, al fin, poder mostrarse en efecto? ¿Y si todos los reparos en ella no fueran más que un contraste, desde el que destacar algo muy digno de reflexión dibujado en un futuro próximo? Porque la exigencia kantiana, fundamento de todas las otras exigencias, de que el hombre no pueda nunca ser tenido como un mero medio, sino siempre como un fin, no es una exigencia burguesa, más aún, es una exigencia que no puede ser nunca cumplida en una sociedad clasista... Con ello, empero, y es lo que fundamenta la ética tonante de la proposición kantiana, se entra en contacto con un estrato cargado en Kant de modo muy especial con el páthos utópico. Se trata, hablando lógicamente, de un «deber ser» que no capitula sin más frente a lo dado. Y no capitula porque los conceptos axiológico aquí envueltos... implican el contenido radical de toda lucha humana por la liberación» ${ }^{9}$. El precedente texto nos revela que, como siempre que el marxismo ha vuelto sus ojos a la ética, el encuentro con ésta ha comportado un encuentro o «reencuentro con Kant», si bien dicho reencuentro -a diferencia, por ejemplo, de lo acontecido un día con otras manifestaciones del marxismo, como el marxismo neokantiano- se ve velado en Bloch por su adhesión a la filosofía hegeliana de la historia.

En un Congreso Internacional de Filosofía celebrado en Stuttgart hace unos pocos años se discutió, entre otras cosas, sobre el peso respectivo del

8 Bloch, en efecto, vio tempranamente al marxismo como «una crítica de la razón pura para la que no ha sido escrita hasta la fecha la correspondiente crítica de la razón práctica» (Geist der Utopie, cit., pág. 304).

9 E. Bloch, Das Prinzip Hoffnung, Gesamtausgabe, vols. V/l y V/2, Francfort del Main, 1959 (hay trad. cast. de F. González Vicén, 3 vols., Madrid, 1977 y ss.), vol. V/2, pp: 1019 y ss. 
influjo kantiano y del hegeliano en el marxismo. La discusión quedó, bastante razonablemente, en unas tablas, puesto que Marx de hallaba filosóficamente hablando- a mitad de camino entre Kant y Hegel, por más que su proximidad al segundo haya gozado comúnmente de mayor reconocimiento -comenzando por el del propio Marx- que su deuda para con el primero. Cierto es que si, en lugar de discutirse de filosofía en general, la discusión se hubiese ceñido con exclusividad al caso de la ética, la balanza se habría inclinado sin reservas hacia el lado de Kant, toda vez que de Hegel, como sabemos, no cabe esperar mucho en tal sentido: esa es, en definitiva, la razón de que todo zurück zu Kant en el marxismo implique de ordinario un über Hegel hinaus por lo que a la ética respecta. Pero no hay que decir que en Bloch no hallamos rastro de semejante vuelta a Kant pasando por encima de Hegel. Pues, por marcado que resulte el acento kantiano de su ética, sobran motivos para preguntarse si -en última instanciano será la voz de Hegel, más bien que la de Kant, la que prevalezca en -o, mejor dicho, sobre- ella.

Como hemos visto, Bloch adeuda a Kant su convicción del carácter moral de la lucha por la realización de «aquello que todavía no ha llegado a ser, en el sentido de lo que todavía no ha llegado a ser lo que debiera» (das NochNicht-Gewordenes als Noch-Nicht-Gutgewordenes), que no es sino la lucha por la realización del bien y de la justicia ${ }^{10}$. Y era así como, según Bloch, el imperativo categórico kantiano apuntaba a un deber ser que sólo podría ser realizado en una sociedad sin clases, constituyendo de ese modo una «anticipación utópica» de semejante sociedad no antagónica. Pero, por muy kantiano que pueda parecernos Bloch en su ética, ya se ha advertido que es también sumamente hegeliano -acaso demasiado- en su filosofía de la historia, que añade a la de Hegel la dimensión de futuro que evidentemente le falta, mas comparte con ella -entre otras muchas afinidades- la tentación escatológica de asignar a la historia un fin, en el doble sentido de una finalidad y de un último término. Con lo que, en consecuencia, el summum bonum corre el grave peligro de quedar transformado, a fin de cuentas, en una categoría histórica más bien que ética: «El contenido esencial de la esperanza»-escribe Bloch- «no es la esperanza misma, sino, en tanto que aquél no permite fracasar a ésta, es existencia sin distancia, presente. La utopía labora sólo por razón del presente a alcanzar, y por eso el presente se encuentra al final... Por eso precisamente la utopía no pretende una distancia eterna del objeto, sino que desea, más bien, coincidir con él como un objeto que ya no es ajeno al sujeto... La aguja magnética de la intención comienza entonces a inclinarse porque el polo está próximo... Lo intencionado como tal presencia, como tal identidad manifestado, no se encuentra -como es, desgraciadamente, fácil de probar- en ninguna parte de lo llegado a ser, pero se encuentra inexcusablemente en la intención inquebrantable hacia ello, así como es reconocible en el proceso histórico universal mismo... La identidad del hombre retornado a sí, con su mundo logrado para él, se ofrece, es verdad, como el mero concepto límite de la utopía, más aún, como el utopissimum en la utopía, y precisamente en la concreta. Pero, sin embargo, 
éste, lo más esperado en la esperanza, al que se llama bien supremo, representa asimismo la región del objetivo final, en la que participa toda proposición seria de objetivos en la lucha emancipatoria de la humanidad» ${ }^{11}$. Bloch concibe la historia, hegelianamente, como un proceso tendente a la consecución de la identidad entre el sujeto y el objeto de la misma. Y confía en hallarse de esta manera en situación de conjugar los factores «subjetivo» y «objetivo» del desarrollo de la Historia, intentando así una vía media entre el voluntarismo revolucionario -más propio, en su opinión del anarquismo, y hasta del fascismo, que del marxismo- y el determinismo socioeconómico, característico de una interpretación socialdemócrata del marxismo que tampoco tendría para él nada que ver con el marxismo auténtico. Pero una cosa es la creencia, éticamente irreprochable, de que las acciones históricas de los hombres persiguen finalidades y otra muy diferente -además de bastante más discutible, al margen ya de su irrelevancia ética- la creencia de que la historia posee en sí una finalidad y, lo que es más, un fin o una culminación, que Bloch bautizará precisamente como «la patria de la identidad» (die Heimat der Identität), considerándola, frente a todos los falsos happy-ends, como el verdadero «final feliz» del proceso histórico ${ }^{12}$.

A mi entender, es ahí donde reside la mayor debilidad de la filosofía blochiana de la utopía, cuyos críticos, sin embargo, no siempre acostumbran a discernir dentro de ella sus registros hegelianos de sus registros kantianos. Un buen ejemplo de una tal actitud indiscerniente lo tenemos en las críticas a Bloch de Leszek Kolakowski, tan penetrantes unas veces como infundadas otras ${ }^{13}$. Y, para no incurrir por nuestra parte en una análoga falta de discernimiento, convendría separar, de entre esas críticas, las insuficientemente fundadas de las que no lo son y se hallan asistidas de suficiente fundamento.

Abordándolas, pues, en ese orden, comenzaremos por aquéllas en las que, en mi opinión, Kolakowski no acierta con el blanco. En lo esencial, dichas críticas se dejan reducir a tres ${ }^{14}$. Primera, el pensamiento utópico de Bloch confunde -como, según subraya Kolakowski, no es infrecuente en el marxismo- la «predicción» del futuro, propia dentro de ciertos límites de la prognosis científica del mismo, con la «creación» de ese futuro que es lo que se pretende conseguir en la programación política de nuestra acción. Segunda, cuando el resultado de tales predicciones no concuerda con los objetivos políticos propuestos, Bloch -al igual que otros marxistas y Kolakowski cita el caso de Lukács- no vacila en alegar que «peor para los hechos». Tercera, nada de extraño tiene entonces que, puesto que la exactitud de las predicciones no parece que importe demasiado, la utopía concreta de Bloch se resista a explicitar su contenido, en cuyo caso -que es tam-

11 Ibid., pp. 366-8.

12 Ibid., pp. 512 y ss.

13 L. Kolakowski, Main Currents of Marxism, 3 vols., Oxford, 1978 (hay trad. cast. de J. Vigil, Madrid, 1980 y ss.), vol. III, cap. XII, «Ernst Bloch: Marxism as a Futuristic Gnosis».

14 Op. cit., pp. 431 y ss. 
bién el de Marx, recuerda Kolakowski, cuando encara el futuro del socialismo- habría que preguntar por qué el empeño de apellidarla de «concreta». Por lo que se refiere a la primera y más fundamental de dichas críticas, no deja de ser cierto que ese cargo -el de la confusión entre pronóstico y programa- es perfectamente imputable a un cierto marxismo pseudocientífico, al que asimismo se ha podido acusar de confundir «predicciones» con «profecías» ${ }^{15}$, pero no necesita recaer sobre el marxismo utópico de Bloch, el cual podría diferir de él por su capacidad adicional de distinguir entre programas estratégicos o tácticos y programas de inspiración abiertamente ética. La precedente dicotomía pronóstico-programa -que Kolakowski, como vemos, hace suya- pudiera resultar inapropiada a estos efectos, por lo que acaso fuera preferible recurrir, siguiendo a Helmut Fahrenbach, a una clasificación tricotómica del pensamiento racional acerca del futuro que nos permita articularlo en los diversos planos de la prognosis, la planificación y la utopía propiamente dicha ${ }^{16}$. De acuerdo con esa clasificación, la prognosis científica del futuro incumbiría a la razón teórica, de la que el futurólogo echa mano, por ejemplo, cuando -partiendo a esos efectos de determinadas tendencias sociales observadas- arriesga conjeturas empíricamente controlables acerca de la probable evolución de la sociedad a lo largo de un período limitado de tiempo. Por su parte, la planificación racional en base a dichas previsiones científicas guardaría con la razón teórica la misma relación que la tecnología con la ciencia, puesto que de lo que se trata en ella es de aplicar la razón teórica -en tanto que razón instrumental- a la confección de estrategias de acción destinadas, por ejemplo, a proveer los medios adecuados para el logro futuro de una serie de objetivos políticos. Por último, el pensamiento utópico en cuanto tal tendría por cometido el examen crítico no de la adecuación de ciertos medios a la consecución de ciertos objetivos o fines dados, sino el de la adecuación -adecuación, se entiende, a nuestra voluntad- de dichos fines en sí mismos, así como la discusión racional de otros posibles fines alternativos, todo lo cual coincide con el cometido que habría que asignar a la razón práctica. Y, a la luz de esa tricotomía, se deja apreciar la insuficiencia de contraponer -al modo de Kolakowski- la prognosis científica y la programación política sin más cualificaciones, pues la programación política pudiera ser encomendada ya sea a la razón instrumental -como en el caso de una concepción tecnológica o, más exactamente, tecnocrática de la política-, ya sea a la razón práctica, como en el caso de una concepción de la política que no renuncie a dar entrada en ella a consideraciones éticas. La distinción entre razón instrumental y razón práctica pertenece, según es bien sabido, al acervo del pensamiento crítico de la Escuela de Francfort, aun cuando fuera ya prefigurada por Max

15 El reproche, del que Kolakowski se apropia en cualquier caso, es de cuño reconocidamente popperiano y se halla formulado en Karl R. Popper, The Poverty of Historicism, Londres, 1954 (hay trad. cast. de P. Schwartz, Madrid, 1961); cfr. también The Open Society and its Enemies, $4^{\mathrm{a}}$ ed., Princeton, 1963, c. XXII.

16 H. Fahrenbach, «Zukunftforschung und Philosophie der Zukunft. Eine Erörterung im Wirkungsfeld Ernst Blochs», en Ernst Blochs Wirkung. Ein Arbeitsbuch zum 90. Geburtstag, Francfort del Main, 1975, pp. 325-61, pp. 327 y ss. 
Weber ${ }^{17}$. Y más adelante tendremos ocasión de aludir a una versión de la misma -debida a Jürgen Habermas- para la que la determinación de los medios más adecuados con vistas a la consecución de un fin determinado, lo mismo da que sea el aumento de la productividad a toda costa que la justa distribución de la riqueza resultante, podría ser confiada a un «uso mononológico» de la razón como el que de la suya hace un experto que reflexiona sobre política económica, mientras que, en cambio, la discusión de aquellos u otros fines -los cuales están lejos de concernir sólo al experto- requiere de un diálogo en el que participen todos los interesados, esto es, requiere de un «uso dialógico» de la razón. Mas, comoquiera que deseemos formularla, lo cierto es que la distinción entre razón instrumental y razón práctica -así como la subsiguiente asimilación del pensamiento utópico a esta última- desarticula la primera objeción a Bloch de Kolakowski; y, una vez desarticulada esa objeción, las otras dos restantes se acabarán también desvaneciendo. Cualquier cosa que sea lo que pensara Lukács a este respecto, la alegación blochiana de que «peor para los hechos» no atenta en modo alguno contra la razón, teórica ni práctica. Pues, mientras para Bloch sería absurdo que una teoría recurra a aquella frase «cuando los hechos se resisten a coincidir con la teoría», su invocación está muy lejos de constituir ningún absurdo si lo que se quiere dar a entender con ella es que «el deber ser no tiene por qué resignarse ante los hechos» y que sin esa falta de resignación no habría manera de transformar la realidad cuando ésta no nos satisface ${ }^{18}$. Pero si el uso práctico de la razón consiste en eso, en cuanto diferente de su uso teórico, tampoco hay que pedir a la razón práctica que «concrete» sus propuestas utópicas más allá de la legítima expresión de nuestro deseo de un mundo más satisfactorio, que podría ser un mundo concebido de modo puramente negativo o por contraste con la insatisfacción que nos produce su situación presente ${ }^{19}$. Contra lo que parece pedirle Kolakowski, la razón práctica no está obligada a precisar cuál haya de ser el contenido positivo de la utopía, pues la misión de la ética, en efecto, no es hacer futurología.

Cuanto acaba de decirse parece sugerir más de un punto de contacto entre el pensamiento de Bloch y el francfortiano, que en sus representantes clásicos, al menos, resulta ser un pensamiento negativo. Bloch comparte con ellos, además de con Marx mismo, la reluctancia acabada de mentar a entrar en los detalles de su diseño utópico, lo que ha sido comparado alguna vez con la aproximación a Dios de la teología negativa y hasta con la prohibición bíblica de recurrir a imágenes de Dios. Pero la consecuencia ética inmediata de semejante negatividad tendría que ser un mayor hincapié en la

17 Véase mi trabajo «A vueltas con la razón», cap. VI de Desde la perplejidad, cit.

18 Das Prinzip Hoffnung, vol. V/2, pág. 1024.

19 Bloch, por lo pronto, asigna -op. cit., vol. V/l, pp. 167 y ss.- un lugar central a der Gegenzug gegen das schlecht Vorhandene dentro de su tratamiento de la «función utópica», aun cuando cuida a continuación de precisar que «esa reacción contra lo que no debiera ser no es -en su dimensión profunda- sólo negativa, sino... contiene en sí la presión hacia un logro anticipado y representa dicha presión en la función utópica». 
capacidad de la razón práctica para decir «no» al mundo presente -para «reaccionar contra lo que no debiera ser» $\mathrm{y}$ «rebelarse ante el mal y la injusticia»- que en su capacidad de afirmación de un mundo concebido como «estación terminal» (Endzustand) del trayecto histórico, en que, tras la Revolución futura, lo que debiera ser, el bien y la justicia hayan de realizarse $\sin$ residuo ${ }^{20}$. En Bloch hay de lo uno y de lo otro, pero la palma de su énfasis se la lleva la dimensión afirmativa de la utopía. Pues la negación de aquello que pensamos que no debiera ser, o de lo que tenemos por malo y por injusto, no requiere necesariamente del concurso de la esperanza, a la que, sin embargo, Bloch no se muestra dispuesto a renunciar bajo ningún concepto.

Para Bloch, en efecto, las preguntas kantianas «¿Qué debo hacer?»y «¿Qué me es dado esperar?» no sólo están interrelacionadas, sino que serán en rigor indisociables, como, por lo demás, lo eran su ética y su filosofía de la historia. Pero esa indisociabilidad es cuestionable y, para cuestionarla, podrían ser oportunas las observaciones de Kolakowski cuando -en el segundo bloque de sus críticas- considera al pensamiento de Bloch como una muestra arquetípica del mito de la identidad en la versión más metafísica del mismo, la de la hegeliana identidad a que hemos aludido entre el sujeto y el objeto del proceso histórico. La esperanza blochiana no es sino la presunción de la final identidad o coincidencia de la subjetividad humana con sus objetivaciones históricas dentro de una sociedad, como la sociedad sin clases, en la que la superación de toda alienación haría posible que los hombres -dueños al cabo de su destino- comprendiesen la historia como un producto suyo y no como un despliegue de acontecimientos externos y ajenos a ellos mismos ${ }^{21}$. Por halagüieña que resulte tal presunción, no todo el mundo está obligado a hacerla suya, como lo prueba el hecho de que Kolakowski se permita reputarla de mítica; pero eso no es, en cualquier caso, lo que estamos ahora discutiendo. Si, por el contrario, se acepta dicho terminus ad quem del desarrollo de la humanidad, será, en cambio, de importancia secundaria que lo interpretamos à la Hegel como la culminación de la historia o prefiramos ver en él, como haría Marx, el auténtico comienzo de esta última, tras la cancelación revolucionaria de la prehistoria. Bloch se inclina obviamente por la interpretación marxista, a la que aportará su propia fórmula según la cual «la verdadera génesis no se encuentra al comienzo, sino al final». Pero eso no hace menos de aquel término una ultimidad, esto es, un punto de inflexión escatológico. Y es contra semejante éschaton contra el que se dirigen los ataques de Kolakowski. En lo esencial, la crítica de Kolakowski a la que ahora nos referimos había ya sido anticipada en una controversia cruzada años atrás entre él y Bloch ${ }^{22}$. Kolakowski compara allí al marxismo con aquellas viejas cosmologías para las cuales todo se mueve en la naturaleza porque todo tiende al reposo final-

20 Ibid., vol. V/2, pp. 1602 y ss.

21 Kolakowski, op. cit., pp. 432-3.

22 Cfr. Maurice de Gandillac, Lucien Goldmann y Jean Piaget (eds.), Entretiens sur les notions de genèse et structure, París-La Haya, 1965 (hay trad. cast. de F. Mazía, Buenos Aires, 1969), pp. 234 y ss. 
mente. De análoga manera, en la utopía marxista -concebida como la esencia del pensamiento revolucionario- la historia tiende a la consolidación de una situación definitivamente estable, de suerte que su mismo motor -a saber, los antagonismos compendiados bajo el epígrafe de la lucha de clases- podría cesar de funcionar, toda vez que su funcionamiento habría dejado de ser ya necesario. Tras la Revolución, y puesto que las clases habrían sido hechas desaparecer, cabría pensar incluso que el marxismo como utopía logre escapar a la necesidad de su transformación en «ideología» en el sentido de Karl Mannheim. Mas suponiendo que el marxismo hubiese de sobrevivir a aquel suceso, ¿qué otras tareas podrían restarle que no fueran tareas apologéticas? Más aún, el marxismo corre el riesgo de ese rebajamiento apologético prima della rivoluzione. Pues, para quienes se encaminan a una meta definitivamente estable y última, siempre cabrá la posibilidad de caer en la tentación de creer que se ha llegado y se pisa por fin terreno firme -sea con la ocasión de Octubre o cualquier otra fecha señalada- y, siguiendo por esa vía, también en la tentación de dedicarse a la apología del presente a la que tan aficionada fue, de hecho, la filosofía hegeliana de la historia, lo mismo da para el caso que se trate del Estado prusiano que del estalinista. Para Kolakowski, el único modo para evitar semejante rebajamiento del marxismo -sea como ideología, sea como utopía- al nivel de la pura apología tendría que consistir en la adopción de un punto de vista radicalmente antiescatológico. Esto es, en la adopción de una concepción de la historia como un proceso inconcluso y, lo que es más, inconcluíble, en el que la tensión que anima el movimiento no se agote, llevándolo a la paralización definitiva. La respuesta de Bloch a tales sugerencias es sumamente reveladora, pues no deja, en principio, de declararse de acuerdo con Kolakowski, cuya proposición -afirma- no haría otra cosa que superar un marxismo desvalorizado, la interpretación del marxismo de quienes -como Karl Löwithsólo alcanzan a ver en él una «escatología secularizada». Pero, por otro lado, se resiste a admitir la idea de una aproximación indefinida o un esfuerzo incesante según el modelo de la frase de Lessing: «Si Dios tuviera en su mano derecha la tendencia a la verdad y en la izquierda la verdad misma, y si yo pudiera elegir entre las dos, le diría a Dios: ¡Señor, dame la tendencia a la verdad, pues la verdad está hecha sólo para Ti! ». Esta última sería, según Bloch, una actitud típicamente «protestante», pero también típicamnte burguesa -la actitud ejemplificada en el Fausto de Goethe, cuyo protagonista no conoce el reposo y constantemente se eleva en sus aspiraciones hacia esferas más altas-, actitud que Bloch contrasta con la actitud «católica» de la Divina Comedia, donde -en el último canto del Paraíso- Dante llega a la rosa celestial y en ese punto cesa toda aspiración. En cuanto a él como marxista -ni católico, pues, ni protestante-, sostiene que ha de haber «una tercera vía» entre el movimiento continuo y la parálisis del devenir, pero la verdad es que no la explicita en ése ni, que yo sepa, en otros lugares de su obra ${ }^{23}$. Comoquiera que sea, sería notablemente injusto pa-

23 No lo explicita, quiero decir, satisfactoriamente, pues el tema de tal tercera vía viene de antiguo en su obra: véase al respecto el capítulo XXI de Subjekt-Objekt. Erläuterungen zu Hegel, Gesamtausgabe, vol. III, 1962 (hay trad. cast. de W. Roces, J. M. Ripalda, G. Hirata y J. Pérez del Corral, México-Madrid-Buenos Aires, $2^{a}$ ed., 1982). 
ra con Bloch adjudicarle la tesis del advenimiento ineluctable de la utopía en el futuro, tesis ésta más propia de un Diodoro Cronos en el improbable supuesto de que el filósofo megárico se hubiese alguna vez abandonado a veleidades utópicas. Por el contrario, a Bloch no se le oculta la esencial frustrabilidad de la esperanza ${ }^{24}$, ya que el proceso histórico se halla indeterminado hasta tanto que su consumación no se produzca, enfrentándose a una crucial alternativa: la de un todo o nada que lo salde con un éxito absoluto o un absoluto fracaso y nos permita decidir si la esperanza se ha visto satisfecha al fin o si, por el contrario, ha sido enteramente en vano. Pero, por eso mismo, la ética -esto es, nuestra respuesta a la pregunta «¿Qué debemos hacer?»- carecería en definitiva de sentido si la respuesta a la pregunta «¿Qué nos es dado esperar?» hubiese de ser «Nada», pues Bloch no da la sensación de haber previsto la posibilidad de ética allí donde no quede rastro de esperanza.

Para acudir a un excelente compendio de la doctrina blochiana de la frustrabilidad de la esperanza ${ }^{25}$ : «El hombre es, sí, un ser utópico, pero es también un ser amenazado. La realidad de este hecho es el origen del temor como oposición a la esperanza, y esto es así porque la totalidad irreversible, la plenitud, sólo se da en el final; su ausencia actual no garantiza el porvenir, que sólo tenemos en la esperanza. El futuro de la identidad no ha sido alcanzado, por esto es frustrable, pues la amenaza no gravita sólo sobre los proyectos a corto y medio plazo; y en la raíz ontológica el efecto aniquilador de la nada es una posibilidad parcial durante el camino y su persistencia puede totalizar la nada en la secuencia final. Ello es la última consecuencia de un sistema abierto, no resuelto a priori, donde se rechaza considerar a la historia como reflejo de la partenogénesis del Logos... La irrupción de los momentos aniquiladores parciales no es sin más asimilable y productiva en el desarrollo dialéctico. Estos hechos o formas históricas son la prefiguración y el anticipo de la nada posible al fin del proceso, como contrapartida del todo también posible es este último estadio... Auschwitz es una muestra clara de hechos no recuperables en la senda del progreso. Se manifiestan como carentes de todo contenido utópico. No ocupan el espacio de la negación, del no productivo, sino son figuras de la nada estéril, al margen y en contra de la esperanza humana. No son una etapa más en el largo camino hacia la utopía última. Son parada y retroceso. Son la presencia tangible, la prueba de que el hombre y la naturaleza pueden abocar a un gran fracaso. La totalidad garantizada sólo se dará al final. Mientras tanto nos acercamos a ella, no en una aproximación indefinida, sino real. Para que la utopía del fin no sea una gran estafa, deberá ser alcanzada alguna vez». Aun si, como el propio Bloch reconocía, el optimismo militante ha de portar crespones negros en su avance ${ }^{26}$,lo cierto, al parecer, es que se avanza, con luto

24 Bloch, «Kann Hoffnung enttäuscht werden?», en Literarische Aufsätze, Gesamtausgabe, vol. IX, 1965, pp. 385-91.

25 José A. Gimbernat, Ernst Bloch. Utopía y esperanza, Madrid, Cátedra, 1983, pp. 99-100.

26 Bloch Tübinger Einleitungin die Philosophie, Gesamtausgabe, vol. XIII, 1970, pág. 241. 
o sin él, de suerte que el vislumbre de aquel éxito final vendría a representar ni más ni menos que el aval de su ética.

¿Hasta qué punto la ética, y en especial una «ética de la intención utópica», necesita de semejante aval? Esto es, ¿hasta qué punto necesita esa ética apoyarse en una filosofía escatológica de la historia? ¿Y cómo evitará, de hacerlo así, su reducción a una variante de las llamadas «éticas del éxito»?

La acusación de rendir un inmoderado culto al éxito ha recaído con frecuencia sobre un cierto marxismo propicio a confundir ética y estrategia, cuando no táctica, o simplemente obsesionado por la Realpolitik. E incluso pensadores marxistas a los que en modo alguno cabría censar dentro de tal marxismo han debido pagar alguna vez tributo teórico, poniendo a prueba su penetración y su sensibilidad éticas, a la pregunta acerca de si el éxito, o el fin, justifica o no el hecho de lograrlo valiéndose al efecto de cualesquiera medios. A diferencia de otras éticas del éxito de acuñación más bien positivista, como un cierto utilitarismo o un cierto pragmatismo, el culto marxista al éxito suele hallarse ligado a un cierto historicismo que convierte a la historia en la piedra objetiva de contraste de la práctica subjetiva. Y es ese culto al éxito el que explica la desafiante impertinencia con que muchos marxistas ponían punto final hace unos años a su discusión con los anarquistas: «Decidnos, a ver, cuándo ha triunfado una revolución anarquista», impertinencia ante la cual no había en verdad mejor respuesta que la de que «un fracaso heroico siempre valdrá cien veces más que un éxito funesto». Del éxito histórico no hay, en rigor, razón para vanagloriarse, puesto que -dado que la historia, según vimos, siempre condena a los vencidos- las cartas de la historia no son sino triunfos: de ahí que la primera tarea de una filosofía retrospectiva de la historia que no dé espaldas a la ética tenga que ser, como lo quería Walter Benjamin, la de prestar su voz a cuantas víctimas sepultara la historia en el silencio. Y alguien en quien, no enteramente sin razón, se ha querido leer la más feroz apología del éxito, se adelantó de hecho en la denuncia de aquel historicismo al descubrir a la, historia como «un epítome de la inmoralidad real» y contraponer a su «Érase una vez» el «No hubierais debido» de la filosofía moral. El marxismo blochiano no se interesa tanto por la filosofía retrospectiva de la historia cuanto por su filosofía prospectiva. Pero así como en la primera el ser triunfante se resiste obstinadamente a ser medido por ningún debe ser, ¿no correrá el peligro la segunda de medir todo deber ser por el triunfo de un ser que en el futuro transforme en realidad nuestras expectativas? El éxito, más metafísico que empírico, dentro de una tal ética del éxito no estribaría ya tanto en la comprobación de que hemos escapado a la derrota a manos de la historia cuanto en la confianza por adelantado de que un día la victoria será definitivamente nuestra.

Ahora bien, una ética de ese género estaría lejos de satisfacer la exigencia primordial de una ética de la intención utópica. Pues, aunque esta última se halle naturalmente interesada en la realización del deber ser, ha de consistir ante todo -como, por lo demás, su nombre indica- en una «ética de la intención», una Gesinnungsethik, en cuanto diferente de una «ética de los resultados» o del éxito, una Erfolgsethik. La falta de ideas claras sobre la ética de la intención ha extraviado en más de una ocasión a la filosofía moral y, de manera muy especial, a la ética política contemporánea. 
Por ejemplo, no deja de aquejar a la invocación por parte de Apelmás arriba mencionada- de una «ética de la responsabilidad colectiva», sobre cuyo carácter innegablemente utópico habremos enseguida de volver. Valga el siguiente párrafo como botón de muestra: «Sacrificando un tanto la precisión de nuestra reconstrucción histórico-filosófica, cabría decir que -con su fundamentación de la autonomía de la 'buena voluntad' legisladora- Kant puso fin a la era de la 'ética de los mandamientos' heterónoma. Al mismo tiempo, sin embargo, inauguró una 'ética de la intención' que subrepticiamente presupone todavía que la buena voluntad de los hombres -lo único que cuenta dentro de ella- ha de alcanzar su recompensa (¿de un Dios que, por así decirlo, retiene para sí la responsabilidad decisiva de la marcha del mundo, incluida la de su historia?) Por el contrario, en nuestro tiempo parece haber dado comienzo la era de una auténtica 'ética de la responsabilidad', dentro de la que -en última instancia- lo importante no es ya tanto la 'buena voluntad' cuanto la realización de lo que es bueno, empresa ésta de la que los hombres habrán ellos mismos de responsabilizarse» ${ }^{27}$. Más que de imprecisa, la reconstrucción apeliana pecaría aquí de equívoca, puesto que «la realización de lo que es bueno» -como sabemos ya sobradamenteno tiene por qué resultar ajena a aquella variedad de la ética de la intención en que consiste la ética de la intención utópica.

Mas, para ser exactos, la que Apel reivindica frente a una ética de la pura intención no es tampoco una ética de los puros resultados o del éxito, sino la ética weberiana de la «responsabilidad política», la Verantwortungsethik $^{28}$, que Weber ciertamente concebía como equidistante de esas otras dos, aun cuando sea más cierto todavía que su propia versión de la misma se escora decididamente hacia la de los resultados y hasta se contrapone frontalmente a la de la intención, pormenor éste que bien vale la pena de una breve digresión.

De acuerdo con el saludable consejo de los exégetas del pensamiento weberiano -que nos advierten sobre la necesidad de contextualizarlo, en especial por lo que se refiere a sus escritos de contenido más directamente político, como hijo que es siempre de su circunstancia-, conviene recordar que el célebre texto La política como vocación ${ }^{29}$ fue redactado en circunstancias tan dramáticas como lo eran el final de la Primera Guerra Mundial y el estallido de la Revolución socialista en Alemania. Por contextualizar a su vez nuestra lectura de ese texto, no hay que decir que las actuales circunstancias -dejando a un lado la nunca descartable posibilidad de una nueva guerra mundial, que por cierto habría de ser la última- tiene poco que ver con las de Weber. El capitalismo, hoy por hoy, ha conseguido marginar la Revolución, relegando su amenaza a aislados focos de la periferia del «sistema». Y allí donde la Revolución logró imponerse, lo hizo para desembocar en el llamado, pues de algún modo hay que llamarlo, «socialismo

27 Apel, «Das Apriori der Kommunikationsgemeinschaft», cit., pág. 427.

28 Ibid., loc. cit.

29 Max Weber, «Politik als Beruf (October 1919)»-hay trad. cast. de F. Rubio Llorente, Madrid, 1967-, en M. Weber, Gesammelte Politische Schriften, $2^{\mathrm{a}}$ ed. de J. Winckelmann, Tubinga, pp. 493-548. 
real». Una situación ésta que muy bien pudiera ser descrita como el advenimiento del ocaso de la utopia y, consiguientemente, del pensamiento utópico, cuyo canto de cisne vendría representado por la obra de Bloch, pero que habría tenido en Weber un lúcido heraldo de su aparentemente irreversible decadencia. Entrando ya en su texto, vamos a concentrar nuestra atención en la antes referida contraposición weberiana entre las éticas de la responsabilidad y la intención. Como es bien sabido, Weber veía en ellas sendos «tipos ideales», lo que equivale a conceder que es improbable que se den en la realidad en estado puro, siendo lo más común que se entremezclen la una con la otra. Pero eso no excluye que, al menos idealmente, quepa distinguir entre ambas y ambas se contrapongan, como dijimos, frontalmente. Ahora bien, ¿en qué consiste exactamente su contraposición? Se diría que en la misma es menester que distingamos cuando menos tres niveles, correspondientes a otros tantos sentidos de la palabra Gesinnung, que en alemán -y, por supuesto, en el texto de Weber, que baraja todos esos sentidos- puede significar, además de «intención», «finalidad» y convicción». La Gesinnungsethik sería, pues, una ética de intenciones y, muy concretamente, de «buenas intenciones». Pero también una ética de fines; y no de fines cualesquiera, sino de «fines absolutos». Así como, por último, una ética de convicciones o principios, «principios incondicionados»y, por ende, considerados inviolables. Es difícil no apreciar, a la luz de ello, que el texto de Weber polemiza con la ética kantiana ${ }^{30}$ en cada uno de esos tres niveles y que es con dicha ética con la que, al hilo de los mismos, habría que confrontar la ética weberiana de la responsabilidad.

Por lo que hace al primer nivel, la ética de la responsabilidad responsabilidad que para Weber, no se olvide, es ante todo responsabilidad política- se contrapone a la de la intención en la medida en la que aquélla es una «ética de las consecuencias», esto es, una ética en la que los efectos de las decisiones tomadas y las acciones emprendidas contarán tanto o más que las intenciones que guiaron al responsable de esas decisiones y acciones al tomarlas o emprenderlas. Kant afirmó, en efecto, que lo único verdaderamente bueno en este mundo era una buena voluntad. Pero con ello, desde luego, no se pergeña un prontuario de instrucciones morales para aviso de políticos. Y tampoco hace falta ser hegeliano para reconocer que, entre otros usos de las buenas intenciones, se halla sin duda el de servir de pavimento en el infierno. Un político, en cualquier caso, no se podría escudar en ellas para excusar las consecuencias de decisiones y de acciones desastrosas. Y decidir o actuar sin tomar en cuenta las consecuencias de sus decisiones o sus actos sería para el una muestra, allí donde las haya, de irresponsabilidad política. De ahí que el balance de esta primera confrontación entre ambas éticas parezca ser -de todas, todas- favorable a la ética de la responsabilidad. Veamos ahora qué sucede en el segundo de los niveles apuntados. La ética de la responsabilidad vendría a ser una ética presidida por la que llamó Weber «racionalidad teleológica», que, a pesar de su nombre, no es en rigor otra que la antes llamada razón instrumental o de los medios, pues se trata

30 Véase al respecto mi trabajo «Ética de la responsabilidad: ¿realización política de la ética o coartada ética de la política?», Letra Internacional, en prensa. 
en definitiva de la racionalidad encargada de la determinación de esos fines que son a su vez medios para la consecución de otros fines dentro de la cadena de medios y de fines que es la política entendida como el arte, o la técnica, de lo posible; mas en cuanto a los fines últimos o valores con que tendría que culminar dicha cadena, Weber no creía que cupiese determinarlos con ayuda de una supuesta racionalidad valorativa -que, para nuestro caso, sería más bien una «racionalidad deontológica», lisa y llanamente coincidente con la que hemos llamado razón práctica- distinta de la racionalidad teleológica. Antes del colapso del sistema tradicional de valores acontecido con la modernidad, la determinación de tales valores, esto es, de tales fines últimos o absolutos, podía venir dada por lo que se consideraba la ley de Dios, una y la misma para todos, que satisfaría así la pretensión de universalidad de la propia ética. Tras la muerte de Dios, o del monoteísmo, se instauró en cambio un pluralismo valorativo o politeísmo en el que cada cual escucharía a su dios o acaso a su demonio. Ello sin duda da satisfacción a un requisito no menos importante de la ética, como es la autonomía de los sujetos morales. Pero plantea el arduo problema de cómo hacer posible éticamente una legislación que a un tiempo se requiere autónoma y se pretende universal. Puesto que Weber no oficiaba estrictamente como un filósofo moral, quizás no quepa reprocharle que no haya prestado a aquel problema la debida consideración. Kant sí lo hizo, aunque es dudoso que consiguiera resolverlo al invitarnos a obrar de modo que queramos que la máxima de nuestra conducta adquiera el rango de una ley general, puesto que distintos sujetos podrían desear la generalización de máximas asimismo distintas e incluso incompatibles entre sí. En consecuencia, tal vez no sea del todo inapropiado decir que, -a este nivel- la confrontación entre Weber y Kant arroja algo así como un empate. Pasemos, para concluir, al tercer y último nivel. En tanto que una ética de convicciones y principios, la ética de Kant resulta ser una ética de «imperativos categóricos»-como el de tratar siempre al hombre como un fin y no tan sólo como un medio-, mientras que la ética weberiana de la responsabilidad únicamente admite imperativos hipotéticos. Ahora bien, lo característico de los imperativos categóricos es su incondicionalidad, que los hace valer independientemente de sus consecuencias y aun a costa del fracaso de aquellos objetivos políticos que -por justos que nos parezcan- no nos estaría permitido conseguir recurriendo para ello a medios injustos. Una ética de imperativos categóricos se negaría a aceptar, por tanto, la regla maquiavélica de que el fin justifica los medios. Como se negaría a aceptar también la lógica del mal menor, puesto que la condena moral de la injusticia no admite grados para ella y ningún bien mayor que la justicia bastaría a conquistar su indulgencia ante violaciones del imperativo categórico kantiano como la consistente, pongamos por ejemplo, en el sacrificio de víctimas inocentes en aras de la consecución de tales o cuales objetivos considerados socialmente prioritarios. El político responsable weberiano, sin embargo, estaría autorizado en ciertos casos a abandonarse a dicha lógica y hasta podría verse forzado a la admisión de que los medios se hallan en ocasiones justificados por el fin. ¿Qué nos impedirá, entonces, identificar a esa su ética con la peor ética del éxito, cuando no con la negación de cualquier ética? Por esta vez, el resultado de la confrontación -al menos si se desea seguir hablando de ética- no puede serle más desfavorable. 
La precedente conclusión, lo reconozco, precisa de alguna matización. Pues, en última instancia, una ética de convicciones o principios no tendría otro remedio que hacer suyo el lema Fiat iustitia et pereat mundus, ya que la misma supervivencia del mundo no valdría -de acuerdo con lo que se acaba de decir- el sacrificio injusto de una sola víctima inocente. Pero, por muy sublimes que sean esos principios, es dudoso que el político, ni nadie, pueda observarlos siempre y sin excepción. Weber tiene probablemente toda la razón cuando llama «odres de viento» a quienes, exentos de responsabilidad por el mundo, piden que éste se hunda si es menester antes que claudicar de sus principios. La cuestión es, no obstante, hasta qué punto habría de ser posible esa claudicación sin un quebranto de la moralidad como el supuesto por la regla de Maquiavelo. Alguna vez se ha dicho que, más que una inmoralidad, la regla maquiavélica entraña una perogrullada, toda vez que el fin condiciona los medios tanto como los medios condicionan el fin. Ahora bien, condicionar no es exactamente lo mismo que justificar. Condiciónenlo o no, los medios más decentes no justificarán jamás un fin indecente, si bien es cierto que medios indecentes pueden condicionar -en el sentido de convertirlo en injustificable- el más decente de los fines; y, por lo mismo, un fin decente no justificará tampoco nunca el recurso a medios indecentes, como Rosa Luxemburg sabía bien cuando escribía: «La práctica del socialismo exige una completa transformación espiritual en las masas degradadas por siglos de dominación burguesa. Instintos sociales en lugar de instintos egoístas, iniciativa de las masas en lugar de inercia, idealismo capaz de pasar por encima de cualquier sufrimiento, etc. Nadie lo sabe mejor, lo describe con más eficacia, lo repite con más obstinación que Lenin. Sólo se engaña completamente sobre los medios. Decretos, poderes dictatoriales de los directores de fábrica, penas draconianas, reinado del terror. Todos ésos no son, en definitiva, sino métodos que frenan aquel renacer» ${ }^{31}$. Lo que el recíproco condicionamiento entre medios y fines revela, por lo tanto, no es que los fines sean indiferentes cuando se da una coincidencia de los medios -como no ha faltado quien sostenga que es el caso del socialismo y el fascismo-, sino sencillamente que los medios no son indiferentes en la persecución de ningún fin. Y que tanto sobre los unos como sobre los otros recae el juicio moral. Pero, por lo demás, la acción política no presenta al respecto ninguna excepcionalidad. Pues quizá sea el momento de advertir que, contra lo que Weber parece suponer, no hay ni puede haber dos éticas, una ética «de los políticos»-algo así como el dharma de la casta políticay otra para los demás mortales. Los políticos, en efecto, tienen con gran frecuencia que violar el imperativo categórico kantiano, pero en tal eventualidad no es cosa de decir que se estén comportando responsablemente, de acuerdo con las reglas de un código moral peculiar, cuando con toda propiedad podría decirse que lo están haciendo inmoralmente, como lo hace cualquiera de nosotros, el que más y el que menos, en su vida particular. Y cuando, para citar el ejemplo de Weber, un político honrado se detiene al llegar a un cierto punto, renunciando a seguir porque no puede obrar de otra mane-

${ }^{31}$ R. Luxemburg, Die russische Revolution, ed. B. Krauss, Hameln, 1957, (hay trad. cast. de D. Acosta, Bogotá, 1976), pp. 81 y ss. 
ra sin traicionar a sus principios, tampoco necesita echar para ello mano de otra ética que la ética practicada, mejor o peor, por el resto de sus semejantes. De hecho, las palabras que Weber pone ahí en boca del político -Ich kann nicht anders, hier stehe ich- no son sino las de Lutero ante la Dieta de Worms. Y las razones que impulsaron a éste a pronunciarlas no eran estratégicas ni tácticas sino, sin más, razones dictadas por la voz de su conciencia.

En resumidas cuentas, pues, cabría concluir que Weber planteó un falso problema al distinguir entre las éticas de la responsabilidad y la intención, pero que dicho planteamiento se acompaña -y de ahí su renombre merecido- del de un problema genuino: el de la relación no entre aquellas dos éticas, sino entre ética y política. La confusión de ambos problemas ha llevado a interpretar más de una vez la distinción weberiana en un sentido un tanto maniqueo, reservando la conducta «racional» y «responsable»para el practicante de la política de moderación y compromiso -expedient politics- que el intérprete favorecería y asignando, en cambio, la violencia extremista repudiada por éste al creyente en una ética de fines absolutos, fanáticamente sostenidos como insusceptibles de cualquier compromiso ${ }^{32}$. Ahora bien, es verdad que Weber -para quien una de las ejemplificaciones de la ética «acósmica» de la pura convicción sería el Sermón de la Montañaprevino, perspicazmente, contra la propensión de quienes repetidamente predican «el amor frente a la guerra» a predicar acto seguido la violencia, la violencia «definitiva» que habría de traer consigo la aniquilación de «toda violencia»; mas no fue menos perspicaz al llamar la atención sobre el hecho de que el poder descansa siempre en la violencia -aun cuando se la apellide de «legítima»-, de suerte que la entrada en la política equivale -son sus propias palabras- a «sellar un pacto con el diablo». Y, en cuanto a la ecuación entre «racionalidad»y «responsabilidad», se ha señalado que esta última palabra no tendría por qué constituir a halo word, una palabra revestida de ningún halo o aureola, siendo como es un término descriptivo que se limita a connotar la predisposición a tomar en cuenta las consecuencias y resultados de nuestras decisiones y actuaciones más bien que las intenciones que las motivan o las convicciones que las respaldan ${ }^{33}$. Aun a riesgo de incurrir en lo que para Weber tal vez no pasaría de la adopción de una actitud infantil ante la política, no está de más que recordemos que esta última se halla a un tiempo solicitada por la razón instrumental y por la razón práctica y ha de atender tanto a una como a otra solicitación: su relación con la ética, empero, tiene bastante más que ver con la segunda que con la primera.

A menudo se piensa que la opción por la razón instrumental, o racionalidad de los medios, frente a la razón práctica o racionalidad de los fines habría de comportar -junto con la preterición de la ética- la renuncia a finalidades absolutas, renuncia que veíamos hace un instante celebrar como si se tratara de la vía más segura para la erradicación del fanatismo político.

32 Cfr. Daniel Bell, The End of Ideology, Nueva York, 1960 (hay trad. cast. de A. Saoner, Madrid, 1967), pp. 288-9.

33 Cfr. Dennis H. Wrong, Introducción a D. H. Wrong (ed.), Max Weber, Englewood Cliffs, 1970, pp. 1-76, pág. 61. 
Esto último no necesita ser en manera alguna cierto, pues nada hay en principio que impida que la adhesión a determinados fines o valores considerados absolutos resulte compatible con la liberal admisión del pluralismo valorativo ${ }^{34}$. Pero tampoco lo primero tendría por qué ser cierto, habida cuenta de que el ejercicio de la razón instrumental -que con frecuencia se reduce, aun si no siempre ni obligatoriamente, a una tecnología al servicio de la dominación política- pudiera convertirse en un fin en sí mismo, susceptible a su vez de absolutación.

Puestos a ofrecer un buen ejemplo de ello, no lo habría mejor que el del O'Brien de 1984 de Orwell cuando afirma que -a diferencia de la época del nazismo alemán o el comunismo ruso, en la que se consideraba aún necesario disfrazar de principios a los objetivos políticos- ha llegado el momento de reconocer que «el objetivo del poder es el poder». La brutal simplicidad de semejante reconocimiento contribuye a la actualidad del texto de Orwell en medida mayor, a mi entender, que la denuncia del totalitarismo comunista ni nazi; y es también la que, al margen de consideraciones relativas a la calidad literaria, lo sitúa a la cabeza de la literatura disutópica -por encima del Nosotros de Zamiatin e incluso de Un mundo feliz de Huxley- en este siglo que por algo se ha ganado la reputación de ser no sólo el del «ocaso de la utopía» o su no-lugar, sino, más aún, la era y el lugar de la disutopía. Después de todo, tanto el «Estado Unido» de Zamiatin cuanto el del «Mundo nuevo» de Huxley persiguen fines no innobles como la felicidad de sus súbditos, aun si ésta linda allí con la despersonalización y la imbecilidad de los mismos-, desvirtuados por el uso de medios deplorables, como un poder capaz de cercenar todo asomo de libertad. Pero para el partido en cuyo nombre habla O'Brien, «el poder no es un medio sino un fin». Su ideología no es, pues, la del Gran Inquisidor -para quien «el mal es un medio destinado a hacer posible el bien»- sino la del poder por el poder sin detenerse en reflexiones sobre el bien ni el mal, poder cuyo ejercicio conduce en el extremo no ya a la destrucción mental o física del individuo -como el caso de D-503 o de John el Salvaje en las novelas respectivas de Zamiatin y Huxley-, sino a su destrucción moral, como en el caso del Winston Smith de Orwell. La novela de este último pudiera interpretarse, más bien que como un vaticinio a treinta y tantos años vista, como una meditación en torno a los estragos de la ideología del poder por el poder; una ideología que, tras haber trocado en un rostro anodino la torva faz con que Orwell la retrata, vendría en definitiva a coincidir con las de las organizaciones políticas burocratizadas y sujetas a la famosa ley de hierro de Michels, la ideología asumida y encarnada por el bureaucratic personality type de Merton o el organization man de Whyte y cuya promoción desde el Estado conducirá a hacerla plasmar en la sociedad totalmente administra$d a$ de Horkheimer hacia la que, en efecto, nos encaminamos, si no estamos ya en ella. Así como los movimientos totalitarios fueron un día llamados «ortodoxias sin doctrina», las concreciones políticas de la ideología del poder por el poder merecerían más bien llamarse «maquinarias ideológicas denalismo? Un dilema positivista», Contrafacta, en prensa. 
sideologizadas», esto es, carente de principios, y constituyen el ardid del que la astucia de la razón instrumental se está valiendo en 1984 para reproducir -sin duda desdramatizándola, pero también, por eso mismo, incrementando nuestra indefensión- la pesadilla de 1984 .

Es muy posible, pues, que nos estemos efectivamente acercando -aun si en un sentido muy distinto del de la frase marcusiana- al «final de la utopía» ${ }^{35}$, lo que explicaría -junto a la innegable pérdida progresiva de actualidad de la utopía en tanto que género no sólo literario, sino asimismo filosófico ${ }^{36}$ - el arrollador auge, no menos innegable, de ese otro género que la filosofía social conoce hoy bajo el nombre de «crítica de la utopía» ${ }^{37}$.

Mas vaya o no camino de su extinción definitiva, el pensamiento utópico parece haber acreditado por lo menos una cierta capacidad de supervivencia gracias a la llamada «transformación teorético-comunicativa del problema de la utopía» ${ }^{38}$. Peter Brenner ha descrito así dicha transformación: «Los problemas del pensamiento utópico contemporáneo han impuesto un replanteamiento de la discusión... Las contribuciones de Jürgen Habermas y de Karl-Otto Apel tratan de hacerse cargo de la situación aporética de aquéllos renunciando al efecto a la propuesta de ideales utópicos positivos a la manera de Bloch... En su lugar, mediante un giro de la argumentación a través de la teoría de la comunicación, tienden más bien a diseñar el marco formal al que ha de remitir forzosamente la formulación de tales ideales» ${ }^{39}$. Ello no excluye, en cualquier caso, que ese diseño posea a su vez un contenido utópico, del que cabría dar acertadamente cuenta diciendo que -en medio de la generalizada falta de fe, y de esperanza, en cualquier propuesta utópica- «la demanda de una razón para la utopía deviene en la utopía de una racionalidad fundamentada» ${ }^{40}$.

35 Para Marcuse -Das Ende der Utopie, Berlin, 1967 (hay trad. cast. de M. Sacristán, Barcelona, 1968)-, «el final de la utopía» significaba, por el contrario, nada menos que su efectiva -ademas, ahí es nada, de inminente- realización.

36 Hermann Lübbe registra aquel viraje como un «cambio de marcha» o de tendencia característico de nuestra coyuntura sociocultural en «Fortschritt als Orientierungsproblem im Spiegel polischer Gegenwartssprachen, en E. Klett (ed.), Tendenzwende?, Stuttgart, 1975, así como en sus libros Fortschritt als Orientierungsproblem, Friburgo, 1975; Unsere stille Kulturrevolution, Zurich, 1978; y Praxis der Philosophie, Praktische Philosophie, Geschichtsphilosophie, Stuttgart, 1978.

37 En una línea en la que fueron precursores, cada uno en su estilo, Ernst Topitsch y Arnold Gehlen -por no hablar de Hans Freyer-, véanse hoy -además del conocido libro de Robert Spaemann, Zur Kritik der politischen Utopie, Stuttgart, 1977-el «proweberiano» de Hans Jonas, Das Prinzip Verantwortung, Francfort del Main, 1979 y el «antiblochiano» de Helmut Schelsky, Die Hoffnung Blochs, Stuttgart, 1979.

38 Cfr. P. J. Brenner, «Aspekte und Probleme der neueren Utopiediskussion in der Philosophie», en Wilhehn Vosskamp (ed.), Utopieforschung. Interdisziplinäre Studien zur neuzeitlichen Utopie, 3 vols., Stuttgart-Tubinga, 1982, vol. 1, pp. 1 1-63.

39 Ibid., pág. 41.

40 Cfr. el excelente trabajo de Rafael del Águila, «Crítica y reivindicación de la utopía: la racionalidad del pensamiento utópico», Revista Española de la Investigaciones Sociológicas, 25, 1984, pp. 37-70, pág. 68. 
Ahora bien, es sabido que las divergencias entre las respectivas filosofías de Habermas y Apel cuentan últimamente tanto como sus primitivas convergencias ${ }^{41}$. Y mientras Habermas se muestra generalmente reticente ante la aplicación del calificativo «utópico» a su pensamiento, Apel al menos ha aceptado alguna vez -si bien de forma matizada- la en estos tiempos tan incómoda calificación ${ }^{42}$. Todo lo cual parece hacer aconsejable concentrarnos en la aproximación del propio Apel al problema de la utopía, mas cuidando de destacar, en primer término, su común denominador con la de Habermas ${ }^{43}$.

Atendamos, por tanto, a dicho denominador común, para lo que quizás sea conveniente retornar ahora una cuestión dejada antes en suspenso. Me refiero a la cuestión de la conciliación de la pretensión de universalidad de las leyes de la moralidad, por un lado, y del requisito de la autonomía de los sujetos morales por el otro. Kant, como se apuntó, dejó sin resolver ese problema, aun cuando fue el primero en planteárselo con absoluta nitidez. Se lo planteó nítidamente, pues la ética, según él, había de legislar para todo el mundo, mas sin por ello excluir, antes al contrario, que cada uno de nosotros sea un legislador. No lo llegó, no obstante, a resolver, pues para resolverlo no bastaba -según tuvimos ocasión de constatar- con la invitación a que obremos de manera que quisiéramos que la máxima de nuestra conducta se convierta en ley universal. En efecto, las máximas de conducta de sujetos diferentes podrían también ser diferentes, de suerte que la fórmula kantiana no garantiza por sí sola la coincidencia, ni tan siquiera la compatibilidad, de sus legislaciones respectivas. De ahí que Habermas haya reformulado en nuestros días de este otro modo la fórmula de Kant: «en lugar de considerar como válida para los demás aquella máxima de conducta que convertirías en ley universal, sométela a la consideración de los demás a fin de hacer valer discursivamente su pretensión de validez» ${ }^{44}$. Lo que la nueva fórmula de Habermas parece sugerir es que, si algún día los hombres alcanzásemos a constituir una auténtica comunidad, tal vez todos y cada uno de los miembros de esa comunidad podríamos hacer algo por ponernos de acuerdo -a través de un diálogo racional, esto es, a través de aquel uso de la razón en que consiste la racionalidad dialógica ${ }^{45}$ - sobre qué máximas

41 Véase sobre mi trabajo «Más allá del contrato social: Venturas y desventuras de la ética comunicativa», cap. VII de Desde la perplejidad, cit.

42 Apel, «Ist die Ethik der idealen Kommunikationsgemeinschaft eine Utopie?», en W. Vosskamp (ed.), Utopieforschung, cit., vol. I, pp. 325-55.

43 Apel, op. cit., no sólo cuida de destacar ese común denominador, sino que incluso se diría que lo exagera, pasando por alto -o acaso, dada la presumible fecha de redacción de su trabajo, no habiendo tenido la ocasión de tomarlo en consideración- el reciente distanciamiento de Habermas (a partir, sobre todo, de la Theorie des Kommunikativen Handelns, 2 vols., Francfort del Main, 1981; hay trad. cast. de M. Jiménez Redondo, en preparación) respecto de algunas de las posiciones anteriormente compartidas por ambos.

44 Habermas, «Diskursethik», en Moralbewusstsein und Kommunikatives Handeln, Francfort del Main, 1983, pp. 53-126, pág. 77.

45 Cfr. «Mas allá del contrato social», cit. 
morales merecerían ser tenidas por leyes universales, qué valores o fines últimos estaríamos dispuestos a compartir, qué necesidades e intereses reconoceríamos como comunes al género humano. La idea de semejante acuerdo no suplanta, al menos en principio, el fuero interno de la moral personal de cada cual, sino intenta más bien complementarlo mediante «un canon crítico con el que sancionar cualquier legislación en el dominio de la moral pública, pues tal legislación sólo podría obligar en la medida en que la totalidad de los implicados hayan participado en su formulación» ${ }^{46}$. Mas el intento es, ciertamente, más fácil de enunciar que de llevar a cabo. $\mathrm{O}$, dicho de otro modo, la dificultad habermasiana de conciliar ambas morales -la moral personal y la moral pública- no tendría por qué resultar menor que la dificultad kantiana de conciliar la aspiración de la legislación de la ética a ser una con la existencia de multitud de legisladores. El diálogo racional, sin duda, es necesario para lograr aquel acuerdo de que nos habla Habermas, pero no está ni mucho menos claro que sea asimismo suficiente. Y, en un mundo como el que nos ha tocado vivir, un acuerdo de esa índole no dejara seguramente de parecer una quimera. Mas, comoquiera que ello sea, de esa quimera se alimenta lo que solemos entender por democracia. Pues, en términos éticos, la sustancia de la democracia se reduce a conceder voz y voto en el diálogo a todos y cada uno de los miembros de la comunidad, comenzando -si es prematuro hablar, como lo es en nuestro mundo, de una comunidad humana universal- por aquellas comunidades de las cuales formamos efectivamente parte dentro de este último.

Para dejar proseguir a Apel con la caracterización de tal «comunidad», digamos, ante todo, que la concibe como una comunidad de comunicación o de diálogo, distinguiendo a continuación entre lo que él mismo llama comunidad ideal y comunidades reales de comunicación. Una comunidad «real» de comunicación se hallará siempre constituida por un determinado «juego de lenguaje» en la acepción wittgensteiniana de esta expresión ${ }^{47}$. Y la «forma de vida» en que consiste puede imponer, por no decir que invariablemente las impone, restricciones dimanantes de la vigencia en su interior de estructuras de dominación. En estas condiciones, es dudoso que los acuerdos adoptados por los miembros de la comunidad se hallen en algún caso enteramente libres de coacciones ni merezcan, por tanto, ser tenidos por «racionales», como no sea en el sentido estratégico o táctico propio de la razón instrumental. En opinión de Apel, sin embargo, no es impensable un juego de lenguaje o una forma de vida -que representaría idealmente algo así como el analogado principal de cualquier otro juego de lenguaje o cualquier otra forma de vida- en que, «en ausencia de dominación», la comunicación fluya irrestricta y el consenso comunitario no responda sino a la única

46 Habermas, «Diskursethik», cit., pp. 86 y ss.

47 Sobre la peculiar asimilación de la filosofía del lenguaje del Wittgenstein de las Philosophische Untersuchungen por parte de Apel, véanse los trabajos de este último «Wittgenstein ind das Problem des hermeneutischen Verstehen», «Sprache als Thema und Medium der transzendentalen Reflexion» $\mathrm{y}$ «Der transzendentalhermeneutische Begriff der Sprache», Transfomation der Philosophie, cit., vol. I, pp. 335-77; vol. II, pp. 31l-29, 330-57. 
coacción de la argumentación. Y sólo si se piensa en tal comunidad «ideal» tendría sentido para Apel demandar que los miembros de la comunidad real rijan su mutua interacción por otra racionalidad que la de la razón instrumental, racionalidad aquélla que llamábamos -frente a la «racionalidad estratégica»o táctica- racionalidad comunicativa o «dialógica». Apel la denomina «racionalidad argumentativo-consensual», en gracia a que no sólo se sirve de argumentos -lo que remonta su genealogía nada menos que al discurso argumentativo del Sócrates de los Diálogos platónicos- sino tiene por objetivo, más allá del contractualismo o neocontractualismo de buena parte de la filosofía moral y política reciente, el logro de un consenso racionalmente fundado entre las partes dialogantes. Y para él vendría, en suma a identificarse con la «razón práctica». En cuanto a la demanda de acudir a esa suprema instancia, dicha demanda entraña el recordatorio de un deber moral, deber que da cuerpo a una étiça que con toda justicia recabaría para sí el título de «ética comunicativa». Únicamente esa ética comunicativa nos podría sacar de la aperplejante situación paradójica de que hablábamos al comienzo del presente trabajo, pues su cometido no es otro que el de instituir para todo ser humano la obligación de «aproximar» cualquier comunidad en la que participe -incluida la humanidad en cuanto comunidad, al menos potencialmente, universal- a las ideales condiciones de la comunidad ideal de comunicación ${ }^{48}$. Con lo que, finalmente, llegamos a la pregunta que inspira la reflexión de Apel en torno a la «utopía dialógica»: ¿es la ética comunicativa una utopía?

Adelantando su respuesta, Apel dirá que no si aquel interrogante hubiera de entenderse como equivalente a la pregunta « ¿Es la ética comunicativa nada más que una utopía?», pero responderá que sí si «la ética de la comunidad ideal de comunicación» es entendida como «una suerte de justificación de la intención utópica» ${ }^{49}$.

En orden a articular su reflexión, Apel procede en tres etapas que nos interesan aquí desigualmente. En primer término, se embarca en una crítica de la utopía que hemos llamado «escatológica» con el fin de deslindar la ética de la comunidad ideal de comunicación de semejante «concepto de utopía gobernado por la filosofía especulativa de la historia» al que más de una vez se ha visto asociada ${ }^{50}$. A continuación, trata de establecer cuál sea desde su particular punto de vista- la auténtica naturaleza de la relación entre «ética y utopía». Por último, y en la línea de su anterior crítica de la utopía, se explaya en consideraciones relativas a la necesidad de confiar la «realización de las condiciones formales de una comunidad ideal de comunicación» a una política ajustada a las exigencias de la «ética» de la responsabilidad ${ }^{51}$. Para nuestros efectos, podemos prescindir de la primera y de

48 Apel, «Ist die Ethik der idealen Kommunikationsgemeinschasft eine Utopie?», cit.. pp. 333 y ss.

49 Op. cit., pp. 338 y ss.

50 Ibid., loc. cit.

51 Ibid., pp. 340-6. 
la última de esas tres etapas, pues tanto el tema de la utopía «escatológica» como el de la «ética» de la responsabilidad -temas que Apel refiere, respectivamente, a Bloch y a Weber- han sido ya tratados por nosotros páginas atrás. Y por lo que hace al tratamiento apeliano de los mismos a través de su propia «crítica de la utopía», a mi entender innecesariamente motivada por la actual ola de crítica neoconservadora del pensamiento utópico, su consideración parece aconsejable posponerla al desarrollo por parte del autor de una prometedora «crítica de la razón utópica» por el momento apenas esbozada ${ }^{52}$. Vayamos, pues, con el segundo y central de los pasos mencionados. En él Apel se ocupa, según quedaba dicho, de la relación entre ética y utopía, esto es, de la pregunta «¿Cómo se relaciona la ética comunicativa con la intención utópica del hombre?».

La ética comunicativa, habíamos adelantado, no se reduce para Apel a una utopía, pero éste no vacila en asignarle la tarea de suministrar una «justificación parcial» (partielle Rechtfertigung) de la intención utópica. He aquí cual es su punto de partida ${ }^{53}$ : «El discurso argumentativo... descansa de hecho sobre una idealización en el sentido de una cesura (Trennung) entre la racionalidad argumentativo-consensual y la racionalidad estratégica. Semejante cesura se halla lejos de resultar característica de las formas humanas de comunicación con anterioridad a, y excepción hecha de, la introducción del discurso argumentativo, e incluso para el propio discurso por ella constituido en cuanto institución no pasa de permanecer al mismo tiempo como una «idea regulativa» que nunca encontrará correspondencia plena en el mundo de la experiencia... Ahora bien, de dicha circunstancia no se sigue en manera alguna que la ética presupuesta en el discurso argumentativo carezca de capacidad de obligar en la resolución de los conflictos prácticos de la vida, pues quienquiera que se comprometa seriamente en una argumentación... presupone desde un comienzo y por anticipado (immer schon) que el discurso bajo las condiciones argumentativas de una comunidad ideal de comunicación no es simplemente un «juego de lenguaje» entre otros posibles, sino que está implicado en cualquier juego posible de lenguaje como la única instancia fundamentadora y legitimadora pensable...». Para poder decir, empero, que ética y utopía se relacionan, es preciso que ambas puedan ser distinguidas entre sí. ¿Cuál será entonces el criterio de esa su distinción? En un primer intento de distinguirlas, tal vez cabría hacer ver que tanto la ética como la utopía anticipan un ideal, pero que -mientras la anticipación utópica versa sobre «una representación empírica de ese ideal, bajo la forma de un posible mundo alternativo»- la anticipación ética enfoca «el ideal más bien como una idea regulativa, nunca completamente realizable en la práctica». Sin ser ello inexacto, no agota, sin embargo, la cuestión

52 Para una primera aproximación a nuestro tema -que a mí personalmente me ha inducido alguna vez («De la intrascendentalidad de la razón», cap. IV de Desde la perplejdad) a conceptuar a la ética comunicativa apeliana no sólo como «utópica» sino también como «escatológica»-, véase Apel, «Das Apriori der Kommunikationsgemeinschaft», cit., pp. 423 y ss.

53 Apel, «Ist die Ethik der idealen Kommunikationsgemeinschaft eine Utopie?», pp. 325-6. 
para Apel, quien insiste en que la anticipación ética lo es también de «una situación ideal» (Idealzustand) que la ética invita -si no con todo lujo de detalles empíricos, al menos tampoco de manera puramente abstracta- a traer a existencia en el futuro, de donde se desprendería una justificación ética no sólo del «deber de superar a la larga la contradicción entre la realidad y el ideal» sino también de la mismísima «fe en el progreso» (Fortschrittsglaube) a comportar por tal superación. Con este colorario entramos, como Apel no puede por menos de reconocer, en los pantanosos aledaños de la filosofía especulativa de la historia, la cual da por sentada -al igual que su antecesora, la escatología judeocristiana- «la realización en el tiempo del ideal conforme a la ley dialéctica de una teleología del decurso histórico». Apel se ve necesitado, por lo tanto, de difíciles ejercicios de equilibrio en orden a sortear un tal escollo. He aquí cuál es su conclusión: «... Al postulado éticamente fundamentado del progreso no hay que asociar ni la renuncia a la progresiva realización del ideal ni la representación de una verificación escatológica en el tiempo... A este respecto, desearía más bien establecer una distinción relevante entre la dimensión ética de futuro del deber ser incondicionado (die ethische Zukunftdimension des unbedingten Sollens) ... y la dimensión filosófico-histórica de futuro de la predecibilidad (die geschichtsphilosophische Zukunftdimension der Voraussagbarkeit)... La decisiva preeminencia fundamentante quisiera, empero, adjudicársela a una teleología de signo deóntico correspondiente a la primera dimensión, desde cuya perspectiva el determinismo de la filosofía especulativa de la historia habría de ceder el paso al siempre renovado intento de una reconstrucción crítica de la historia animada por una intención práctica...» ${ }^{54}$. Ya que no una pieza de estricta filosofía especulativa de la historia, la de Apel resulta cuando menos -de nuevo según su expreso reconocimiento- una «cuasipieza» (quasi-geschichtsphilosophische) de dicho género filosófico, a saber, una pieza de literatura «cuasi-utópica» que me temo que también siga resultando «cuasi-escatológica».

Con mayor propiedad que a través de su discutible recurso a una «teleología de signo deótico» llamada a reafirmar nuestra desalentada fe en el progreso, lo que Apel trata de expresar en los párrafos precedentes -y, de manera muy especial, su reivindicación de la ética frente a la filosofía de la historia- podría tal vez ser expresado echando mano de la distinción, recogida por Neusüss, entre un modelo «horizontal» y un modelo «vertical» de la utopía ${ }^{55}$. En el primero de ambos casos, la utopía -esto es, el correlato

54 Hay que advertir a este respecto que, contra lo que Apel -op. cit., pp. 327 y ss.parece sugerir, no toda filosofía especulativa de la historia necesita ser escatológica: así se explica que, por una parte, la tradicional distinción entre filosofía «analítica» y filosofía «especulativa» de la historia se halle hoy sujeta a revisión (cfr. Haskell B. Fain, Between Philosophy and History. The Resurrection of Speculative Philosophy of History Within the Analytic Tradition, Princeton, 1970), mientras, por otra parte, ni siquiera parezca descabellada la idea (cfr. Gerald A. Cohen, Karl Marx's Theory of History. A Defence, Oxford, 1979) de aplicar el instrumental analítico a la defensa de una cierta filosofía especulativa de la historia, como lo sería el materialismo histórico, una vez depurada de residuos escatológicos.

55 A. Neusüss, Utopie, cit., Introducción, III, 2, donde Neusüss se inspira en la distinción de Paul Tillich, Kairos und Utopie, Stuttgart, 1963, entre una línea «horizontal» 
de la intención utópica- constituiría ni más ni menos que la coronación del desarrollo lineal de la historia, en la que el ser acabaría al fin coincidiendo con el supremo bien tras la efectiva realización del ideal utópico. En el segundo caso, en cambio, la utopía incidiría más bien en perpendicular sobre el proceso histórico, esto es, sobre tal o cual momento dado de éste, reactualizando en cada uno de esos instantes el contraste entre la realidad y el ideal -la tensión entre el ser y el deber ser- y fragmentando, así, el cumplimiento de la intención utópica, que no hay por qué pensar que alcance definitivo cumplimiento. Se trata, como vemos, no sólo de distintos modelos de utopía, sino asimismo de distintas concepciones de la ética, a saber, una concepción teleológica de la misma -indisolublemente ligada en este caso a una filosofía escatológica de la historia- y otra de corte deontológico, que no requiere en principio del concurso de ninguna escatología ${ }^{56}$. En una obra como la de Bloch coexisten ambos modelos y ambas concepciones. Pero, a fin de cuentas, la utopía horizontal y la ética del bien supremo terminarán por imponerse dentro de ella sobre la ética del deber y la utopía vertical ${ }^{57}$. Y, si sólo existiera aquel modelo de utopía y aque-

y una línea «vertical»-relacionadas ambas con «la dimensión suprahistórica del reino de Dios»- dentro de las «profecías utópicas», distinción ésta teológica de la que no podemos apropiarnos sin modificar su sentido, pues -tal y como Tillich la formula (op. cit., pp. 150 y ss.)- aludiría más bien a un plano metahistórico, paralelo acaso al de la historia, pero no obstante diferente de -si no ajeno a- la historia misma.

56 Por lo común, una y otra concepción -como uno y otro modelo- se asocian respectivamente a actitudes eudemodistas o autonomistas, según parece registrarlo el propio Bloch en su intento -a que nos referimos a continuación- de propugnar la coexistencia, y hasta la comunión, de las distintas tradiciones de la «utopía social» y del «derecho natural» (Naturrecht und menschliche Würde, Gesamtausgabe, vol, VI, Francfort del Main, 1961; hay trad. cast. de F. González Vicén, Madrid, 1980): «Aun cuando las utopías sociales y las teorías iusnaturalistas estaban de acuerdo en lo decisivo, en el logro de una sociedad más humana, entre ambas se dan diferencias muy importantes. Concisamente expresadas, estas diferencias son: la utopía social estaba dirigida a la felicidad humana; el derecho natural, en cambio, a la dignidad humana. La utopía social diseñaba de antemano situaciones en las que dejan de existir los agobiados y oprimidos, mientras que el derecho natural construye situaciones en las que dejan de existir los humillados y ofendidos... Las utopías sociales están dirigidas principalmente a la dicha o, por lo menos, a la eliminación de la necesidad y de las circunstancias que mantienen aquélla. Las teorías iusnaturalistas, en cambio, están dirigidas predominantemente a la dignidad, a los derechos del hombre, a garantías jurídicas de la seguridad o libertad humanas, en tanto que categorías del orgullo humano. Y de acuerdo con ello, la utopía social esta dirigida, sobre todo, a la eliminación de la miseria humana, mientras que el derecho natural está dirigido, ante todo, a la eliminación de la humillación humana: la utopía social quiere quitar de enmedio todo lo que se opone a la eudemonía de todos, mientras que el derecho natural quiere terminar con todo lo que se opone a la autonomía y a su eunomía». ( Op. cit., Vorwort, pp. 13-4; pp. 233 y ss.).

57 Para ser exactos, Bloch -tal vez porque, en su filosofía, tanto la «utopía social» como el «derecho natural» se hallan abiertos por igual a una interpretación escatológica no alcanza a ver la posibilidad de conflicto entre una y otro, lo que le lleva a proponer -como es característico de su pensamiento- «su síntesis en el marxismo» (Ibid., pp. 235-8; cfr. Felipe González Vicén, «Ernst Bloch y el Derecho natural», Sistema, 27, 1978, «Ernst Bloch Philosophie der Utopie», en W. Vosskamp, ed. op. cit., pp. 293-303). 
lla concepción de la ética, nada tendría de extraño que el descrédito actual de la utopía comportase de paso la todavía más grave ruina de la ética. El curso de la historia, desde luego, no parece enderezarse en la por Bloch soñada dirección de la consumación del mito de la identidad del sujeto y el objeto, que -en su concreción más directamente política- tendría que concretarse en la identificación del hombre como individuo y el hombre como ciudadano, o de la sociedad civil y el Estado, con la consiguiente abolición de este último y su sustitución por una democracia radical. Una identificación cuya conquista sería la tarea histórica asignada por Bloch, como antes por Marx mismo, al socialismo ${ }^{58}$.

No hay que decir que esa conquista no se ha producido hasta la fecha ni tiene el menor viso de producirse en un futuro previsible. En el llamado mundo socialista, la abolición del Estado se halla sin duda más allá de cualquier poder humano de imaginación, y -antes que a la progresiva superación del divorcio entre la sociedad civil y el Estado- asistimos en nuestros días a un recrudecimiento de su mutua oposición. Y, en lo que concierne al mundo capitalista, son legión los observadores que han llamado insistentemente la atención sobre el desbordamiento de la Nación-Estado clásica, pero por obra y gracia de las grandes corporaciones multinacionales -constituídas, a su vez, en una suerte de organización superestatal a escala mundial-, lo que no sirve mucho que digamos para levantar de su postración a nuestros enervados ánimos libertarios. Mas no por ello habríamos de hacer virtud de la necesidad, abandonándonos a un cántico a las excelencias del Estado -así se trate del llamado «Estado social»-, la resistencia frente al cual, por lo

58 Por proseguir con Naturrecht und menschliche Würde, se lee allí: «Marx descubrió la propiedad como determinante entre los demás derechos del hombre, razón por la cual éstos aparecen tanto más truncados. Ahora bien, al mostrar Marx la propiedad como limitación burguesa en los derechos del hombre, ¿niega, por eso, las otras exigencias de los mismos, como la libertad, la resistencia del pueblo a la opresión o la seguridad? En absoluto, como es evidente; su intención está dirigida, al contrario, a un despliege consecuente, a un despliegue no impedido ni a la larga aniquilado por la propiedad privada, de todos esos derechos humanos... Solidaridad en el socialismo significa que, en lo relativo a los derechos del hombre, l'homme no representa ya el individuo egoísta, sino el individuo socialista, el cual, según la profecía de Marx, ha transformado sus forces propres en fuerzas político-sociales. De tal suerte que le citoyen, que en la Revolución francesa vivía en un más allá abstractamente moral, es ahora rescatado de dicho más allá y retrotraído a la terrenalidad de la humanidad en sociedad. Y sólo entonces, dice Marx, se habrá llevado a cabo la emancipación del hombre» (op. cit., pp. 203-6). «El Estado, en tanto que socialista, sería según la consigna de Marx, el Estado en su forma completamente invertida, no comparable con ninguna de las anteriores. El Estado funciona simplemente como servidor de su propio acabamiento, un andamiaje y unos travesaños transitorios para la edificación del no-Estado... En lugar de la antigua sociedad burguesa con sus clases y sus oposiciones de clase, aparece una asociación en la que el libre desenvolvimiento de cada uno es la condición para el libre desenvolvimiento de todos (Manifiesto comunista)... Y como ningún Estado de Derecho puede ocultar a la larga la esencia catastrófica del capitalismo, lo mismo que tampoco ningún efecto estalinista, por diversas que sean sus causas, puede ocultar el triunfo más humano de todos los triunfos, el triunfo del socialismo, hay que concluir que estas palabras de Marx tienen validez ante rem, pero también in re y post rem; su verdad es index sui et falsi» (Ibid., pp. 309-10). 
demás, no debiera tampoco confundirse con el intento de desmantelarlo en sus aspectos asistenciales y benefactores por parte de la reacción neoliberal o neoconservadora, donde ambos «neo-ismos» -neoliberalismo, neoconservadurismo- merecerían más bien ser reputados como «paleoismos». La lucha por una democracia radical, en cualquier caso, podría seguir valiendo éticamente la pena del esfuerzo aun cuando ya no la avale filosofía ninguna de la historia ni responda a otra intención utópica que aquélla que no precisa de horizontes -diríase hoy que perdidos, más aún que lejanos- para perseverar. Y algo por el estilo vendría a ocurrir con nuestra apuesta a favor de la utopía dialógica, que para nada necesita envolver juicio alguno sobre su harto dudosa verosimilitud histórica. Pues pocas cosas, en efecto, resultan tan inverosímiles por el momento como -para servirnos de la bella descripción de Emilio Lledó- «la utopía de la comunicación plena, de un alcance mayor que aquel heraldo de la Ilíada, Stentor, cuya voz recuerda Aristóteles en la Política y cuyo alcance marca el límite fuera del cual ya no hay pólis » 59 Lo que una advertencia así pretende no es negar, rousseaunianamente, que la auténtica democracia sea posible en nuestra complejas sociedades actuales a consecuencia sólo de su complejidad. Después de todo, la tecnología de la comunicación pone actualmente a nuestra disposición un abundante repertorio de voces estentóreas capaces de llegar a los confines de cualquiera de dichas sociedades e incluso de trascenderlos ampliamente. Mas lo que ni la voz más estentórea podría garantizar es que la comunicación dentro de ellas sea suficientemente plena en el sentido de sustraída a la manipulación, recíproca, simétrica y, en una palabra, democrática. Nada digamos, pues, de la comunidad universal de comunicación. Por «universal» que fuese tal «comunidad»-hoy por hoy, a decir verdad, inexistente-, seguiría presumiblemente siendo una comunidad real, no una comunidad ideal de comunicación en que reinase lo que cabría llamar una absoluta «transparencia comunicativa». La real universalidad de la comunicación -ya de por sí improbable- estaría lejos, ciertamente, de asegurarnos que ésta sea, además de realmente universal, idealmente transparente.

De cualquier modo, la contraposición entre opacidad y transparencia comunicativa da pie a la distinción de Apel entre el simple «acuerdo fáctico» de una comunidad real y el «consenso argumentativo» de la comunidad ideal de comunicación, concebida como un a priori y hasta como una condición trascendental de posibilidad de la propia ética comunicativa ${ }^{60}$. Sería, en efecto, opaca aquella situación comunicativa en la que no fuera posible di-

59 E. Lledó, «La realidad de la utopía», en Ramón Garda Cotarelo (ed.), Las utopías en el mundo occidental, Universidad Internacional Menéndez Pelayo, 1981, pp. 13-32, pág. 25.

60 En rigor, las tradiciones y modelos invocados por Apel -«Ist die Ethik der idealen Kommunikationsgemeinschaft eine Utopie?», cit.- van desde la «opinión pública razonante» (räsonierende Offentlichkeit) kantiana al «discurso descargado de acción» (handlungsentlastetes Diskurs) habermasiano, pero la lógica interna de su «comunidad ideal de comunicación» no podría contentarse con menos que la más absoluta transparencia comunicativa, en cuanto tal una variedad particular del «mito de la transparencia» social y política (cfr. mi trabajo «En torno al mito de la transparencia», Diálogos, en prensa). 
lucidar si un acuerdo ha sido fruto de la fuerza de los argumentos o ha sucumbido al argumento de la fuerza. Y la frecuencia de semejantes situaciones hace pensar que acaso haya mayor urgencia en combatir la opacidad que en precisar en qué consista la transparencia de la comunicación colectiva, de la misma manera que la disposición a denunciar una injusticia parece de ordinario más urgente que la elaboración de una teoría de la justicia. Dejando a un lado otros inconvenientes en los que no podemos detenernos, la insistencia apeliana en la necesidad del logro de un consenso no debiera hacernos olvidar aquella urgencia, pues los conflictos reales, desde luego, rara vez se resuelven por medio de consensos ideales. Y, cualquier cosa que sea lo que hubiere de acontecer en el seno de una comunidad ideal de comunicación, la comunicación humana no es, por lo común, ni enteramente opaca ni absolutamente transparente, sino ambiguamente translúcida, de suerte que en ella alienta tanto el riesgo de la incomunicación como la efectiva posibilidad de hacer algo por superarla. La ética comunicativa que en cada caso impone la opción por esta última es declaradamente utópica, lo que quiere decir que -puesto que carece, a no ser como tentativa, de la consistencia real propia de un hecho- de nada vale preguntarnos, transcendentalmente o no, por las condiciones empíricas de su posibilidad. Por el contrario, «la utopía de la comunicación plena»-que no es escatológica ni cuasiescatológica, sino una aspiración perpetuamente insatisfecha, aun si por eso mismo perseverantemente reasumida por la intención utópica- entrañaría más bien, contra lo que parece creer Apel, un problemático e incierto $a$ posteriori ${ }^{61}$.

De cuanto acaba de decirse se sigue, en fin, que la utopía de la comunicación plena tiene bastante más que ver con la verticalidad que con la horizontalidad utópica. En cuyo caso, ¿no vendría a coincidir ese concepto vertical de utopía -que hacemos aquí nuestro- con el que el propio Neusüss ha caracterizado, y criticado, como «el concepto conservador de la utopía»? ${ }^{62}$. Si atendemos a su caracterización de tal concepto conservador de la utopía -la utopía como instancia ética, perpendicularmente levantada sobre el plano histórico en el que se debate nuestra vida política-, la respuesta es incuestionablemente afirmativa, pues la concepción de la utopía que defendemos se asemeja más a aquélla que a cualquiera de las alternativas progresistas conocidas. Mas si atendemos a su crítica del concepto conservador de la utopía -la instancia utópica como ajena al curso de la historia, lo que convertiría en ociosa y hasta en indeseable toda lucha política por mor de la utopía-, querría confiar en que nuestra concepción de la utopía escape a dicha crítica, pues de ella no se deriva, que yo sepa, ninguna apología de la inacción. El concepto conservador de utopía que Neussüs critica, aunque no así el que caracteriza, es un concepto decididamente ahistórico. Pero la utopía que proponemos no es en manera alguna ucrónica, sino se halla invariablemente in-

61 Véase, además del trabajo antes citado, mi contribución «El aposteriori de la comunidad de comunicación y la ética sin fundamentos» a Adela Cortina (ed.), Estudios sobre la filosofía de Karl-Otto Apel, en preparación.

62 Así lo ha hecho, op. cit., loc. cit., remitiendo en este caso a Hans Freyer, Die politische Insel. Eine Geschichte der Utopien von Plato bis zur Gegenwart, Leipzing, 1936, pp. 165 y ss. 
cardinada en el momento histórico. Y en cuanto al conservadurismo, no se trata tampoco de sustituir la ardiente -aun si no siempre lúcida- mirada progresista por el gélido modo conservador o neoconservador de escudriñar el mundo, en que la indiferencia hacia la suerte de la humanidad parece ser el precio a pagar por la lucidez. Conservadurismos, lo mismo que progresismos, los hay de muchas clases. Al conservadurismo del príncipe Salina en la novela de Lampedusa, para quien algo tiene que cambiar con el fin de que todo siga igual, cabría oponerle, por ejemplo, el de que todo tiene que cambiar para que algunas cosas puedan ser conservadas. Que es lo que parecía estar pensando Marx al plantear, conservadoramente, el conjunto de opciones que pasaron a conocerse bajo la forma de dramática disyuntiva entre el «socialismo»-socialismo, en el fondo, considerablemente más utópico de lo que él mismo hubiera nunca concedido- y la «barbarie» disutópica ${ }^{63}$. Entre esas cosas a conservar gracias al socialismo, se habría de incluir, por cierto, la posibilidad de que aún tenga sentido hablar de ética.

La utopía vertical, como hemos dicho, no propicia la inacción. Pero, con todo, alguien acaso se pregunte si la acción revolucionaria -en cuanto diferente de la mera rebelión puntual, que simplemente nace de la negación del presente- no requiere, más o menos blonchianamente, de un horizonte de futuro. Bien miradas las cosas, sin embargo, habría que recordar que hasta la misma utopía horizontal cobra sentido sólo si pensamos que ese horizonte -entrevisto en el sueño revolucionario de la lucha por un mundo mejortiene que irse alejando de nosotros precisamente en la medida en que tratamos de avanzar hacia él. Y que, por irónica que parezca, tal conclusión no es sino la conclusión más lógica a extraer de la fundamental inconclusión de la historia humana. Como advirtiera a este respecto Albert Camus: «En teoría, la palabra revolución conserva el sentido que tiene en astronomía, esto es, el sentido de un movimiento que consiste en el cierre de un ciclo... Pero, por eso mismo, puede decirse que aún no ha habido ninguna auténtica revolución en la historia y que, si la hubiera, tendría que ser la definitiva... A la espera de esa revolución, si es que ha de haberla, la historia de los hombres es, en cierto sentido, la suma de sus rebeliones sucesivas» ${ }^{64}$. Una suma con toda probabilidad inacabable, salvo que el horizonte utópico pudiese al fin ser alcanzado, resolviéndose en optimismo o pesimismo el saldo de la historia. Pero no está muy claro que de esa imaginería escatológica se siga algún provecho revolucionario. Y ni siquiera es casual que el horizonte sólo nos parezca alcanzable cuando estamos parados. Lejos de inducirnos al quietismo, la ética como utopía -la utopía ética- nos podría, en cambio, seguir dando -incluso si la noche y la niebla de la disutopía han hecho desaparecer de nuestro campo de visión todo horizonte- más de una razón, tal vez las únicas razones, para no estarnos quietos.

63 Desde otros presupuestos, Felipe Martínez Marzoa, La filosofía de «El Capital», Madrid, Taurus, 1983, pp. 156-67, propone certeramente una lectura «conservadora» de aquella disyuntiva y, en general, de la idea de revolución en Marx, para quien «la verdadera alternativa no es entre revolución y conservación, sino entre conservación revolucionaria y liquidación abstracta».

64 A. Camus, L'homme révolté, París, 1951 (hay trad. cast. de L. Echávarri, Buenos Aires, 1953), pp. 100-2. 